\title{
Evaluation of the Effects of Corruption in the Armed Conflict in Northeast and Other Situations of Violence in Nigeria
}

\author{
Hagler Okorie \\ Abia State University, Uturu, Nigeria \\ Email: haglersoco@gmail.com
}

How to cite this paper: Okorie, H. (2018). Evaluation of the Effects of Corruption in the Armed Conflict in Northeast and Other Situations of Violence in Nigeria. Beijing Law Review, 9, 623-660. https://doi.org/10.4236/blr.2018.95036

Received: July 25, 2018

Accepted: November 20, 2018

Published: November 23, 2018

Copyright $\odot 2018$ by author and Scientific Research Publishing Inc. This work is licensed under the Creative Commons Attribution International License (CC BY 4.0).

http://creativecommons.org/licenses/by/4.0/

\section{(c) (i) Open Access}

\begin{abstract}
Corruption is regarded as the abuse of public office for private gains. This is done when an official accepts, solicits, or extorts a bribe. Also, public office is abused when private agents actively offer bribes to circumvent public policies and processes for competitive advantage and profit. It can also be abused for personal benefit even if no bribery occurs, through nepotism and clannishness, the theft of state assets or the diversion of state revenues. Corruption in Nigeria has been responsible for the pernicious enervation of government and governance whether military or democratic since independence. Corruption engenders the occurrence of conflicts involving large-scale organized violence. This is because of how endemic corruption is and the various attacks it has on the life, progress and development of the state. It has robbed the state of peace and progress; unity and harmony. Again, this results into class conflict which materializes into various forms of revolution as carried out by the Niger Delta militants, the Indigenous Peoples of Biafra and the internecine bloodletting of the Fulani Herds men marauding across the country without let and hindrance as a result of corruptive nepotism and clannishness pervading within the Federal powers. This work analyzes the catalyzation of corruption on the armed conflict in the Northeast and other situations of violence in Nigeria. The work also examines the domestic legal regimes established to stamp out this kleptocratic menace and concludes that there is the need to strengthen these laws, especially by the further amendment of the 1999 Constitution of the Federal Republic of Nigeria, to constitutionally establish an independent and special court to try corruption cases in the country.
\end{abstract}

\section{Keywords}

Corruption, Armed Conflict, Violence, Northeast, Nigeria, Boko Haram 


\section{Introduction}

Corruption in Nigeria represents a threat to the stability and security of the State, undermining our ethical values, and the principles of justice and jeopardizing national development, the rule of law and equity. The State of Nigeria has been facing corruption which has attained levels of gross and egregious theft, for which no possible moral or historical justification can be adduced, and which has played a major role, both in mass impoverishment of the peoples of Nigeria and in the alienation of the led from the leadership. It has been ascertained that widespread corruption especially in societies beset by mass poverty and very high levels of unemployment, has a deeply corrosive effect on trust in government and contributes to crime and political disorder. ${ }^{1}$ At the extreme, the political ascendance of naked self-interest intensifies social inequalities, encourages social fragmentation and internecine conflict and propels a corrupt society into an unremitting cycle of institutional anarchy and violence. ${ }^{2}$ Unbridled corruption leads to state fragility and destructive conflict and which plunges a state into political instability and destroys legitimacy of government.

Since independence in 1960 in Nigeria and through the republicanism in 1963, the view has been widely held that corruption conspired with political instability and used the State of Nigeria as a playground. The country's "leaders came, saw and squandered". ${ }^{3}$ Historically, all the coup detats in Nigeria anchored their mission on the need to stamp out corruption from the polity which has pervaded among the leaders. In the Western election crises in 1964 and 1965, it was observed that all sorts of deviousness, gerrymandering and manipulations were used to win the election. Electoral Officers were instructed to recognize only certain nomination papers. ${ }^{4}$ At that time, Prime Minister identified corruption as a national problem and proposed long-term solution. ${ }^{5}$ Certainly, the coup plotters who executed the first bloody coup d'etat in Nigeria did not share in the Prime Minister Balewa's long term planning and they struck. Their mission was to purge from the nation evils of regionalization, tribalism, immorality and corruption. ${ }^{6}$

From the Yakuba Gowon's 1966 bloody counter-coup d'etat to the present endemic and systematic corruption is one of a constellation of interrelated de-

\footnotetext{
${ }^{1}$ S. Atuobi (2007). Corruption and State Instability in West Africa: An Examination of Policy Options, (KAIPTC Occasional Paper No. 48, 2007) 1, 2. See also, UN Office for West Africa (UNOWA), Life After State House. Addressing Unconstitutional Changes in West Africa (Issues Papers, March 2006).

${ }^{2}$ R. Theobald (1990). Corruption, Development and Underdevelopment ( $6^{\text {th }}$ ed.). Basingstoke: Macmillan.

${ }^{3}$ H. Kukah (1999). Democracy and Civil Society in Nigeria. Ibadan, Oyo: Spectrum Books Limited. ${ }^{4}$ O. Ikejiani et al. (1968). Nigeria: Political Imperative-Desiderata for Nationhood and Stability. Enugu: Fourth Dimension Publishing Co. Ltd. See also F. Asogwah and P. Okoli (2008). Economic Crimes and National Development. (Enugu: Institute for Development Studies).

${ }^{5}$ See, F. Asogwah et al, ibid., 18.

${ }^{6} \mathrm{~T}$. Clark (1991). A Right Honourable Gentleman. The Life and Times of Alhaji Sir Abubakar TafawaBalewa. Zaria: Hudahudo Publishing Company Ltd.
} 
velopment challenges endogenous to Nigeria. Corruption has stultified socio-economic and political life of the country. Public infrastructure is lacking, exacerbated by poor economic life of the people (as education and health facilities are beyond the reach of average citizens) and these lead to the ignition of frustration and bottled anger against the state and leaders. This finally transmutes into strings or pockets of violence or hem of rebellion as we are witnessing in some areas in Nigeria today.

This work is organized as follows: Firstly, a theoretical framework and understanding of corruption. This is followed by the analysis of armed conflict in the northeast and other situations of violence in Nigeria. The next is the examination of the legal instruments against corruption. This section is followed by the assessment of the need to establish independent and special court for the trial of corruption cases in Nigeria and the imposition of life jail term for punishment of corruption.

\section{Defining Corruption}

Defining Corruption is important in the context of this paper in order to specifically situate our focus and discourse within the framework of this topic. However, this is not a mean feat. This is owing to the fact that corruption, as indicated earlier, is a social, legal, economic and political concept enmeshed in ambiguity and consequently encouraging controversy. The concept of corruption is difficult to define to cover the broad range of human actions. Corruption like law, truth, beauty, has no universally acceptable definition.

Corruption is defined as "depravity, perversion, or taint, and impairment of integrity, virtue, or moral principle. The act of doing something with an intent to give some advantage inconsistent with official duty and the rights of others to procure some benefit either personally or for someone else, contrary to the rights of others."

The World Bank defines corruption as:

the abuse of public office for private gains. Public office is abused for private gain when an official accepts, solicits, or extorts a bribe. It is also abused when private agents actively offer bribes to circumvent public policies and processes for competitive advantage and profit. Public office can also be abused for personal benefit even if no bribery occurs, through patronage and nepotism, the theft of state assets or the diversion of state revenues $^{8}$

Indeed, the World Bank definition is commendably broad to cover most of the corrupt acts in Nigerians. Corruption and economic crime are kindred of same bed-fellow and have a common denominator, which is abuse of power. It can also be put elaborately, using power in a dishonest or illegal way in order to

${ }^{7}$ B. Gammer (1999). Black's Law Dictionary. (Eight Ed.). USA: West Publishing Co.

${ }^{8}$ World Bank, "Helping Countries Combat Corruption" in I. Ayua. (2002) Problems of Corruption in Nigeria. Lagos: Nigerian Institute of Advanced Legal Studies. 
get an advantage for oneself.

Under the Economic and Financial Crimes Commission Act, 2004, it defines what it terms "Economic and Financial Crimes". It is defined thus:

...the non-violent criminal and illicit activity committed with the objectives of earning wealth illegally either individually or in a group or organized manner thereby violating the economic activities of government and its administration and includes any fraud ... money laundering, embezzlement, bribery, looting and any form of corruption malpractices ... etc. ${ }^{9}$

Grantedly, this definition is so wide and accommodates all shades of economic crime. However, the definition is dwarfed and largely inelegant as it is bereft of the ingredients of nepotistic cronyism which is one of the bane of progressive Nigeria. ${ }^{10}$ In the same vein, the Corrupt Practices and other Related Offences Act, 2003 defines "corruption" to include bribery, and other related offences. ${ }^{11}$ In Yusuf v. Obasanjo, ${ }^{12}$ the Court of Appeal held that the:

...term corrupt practices denotes or can be said to connote or embrace certain perfidious and debauched activities which are clearly felonious in character being redolent in their depravity and want of ethics. They become the hallmark of a decayed nature lacking in conscience or principles.

Judicial views and definition of corruption are not quite different from the ones provided by the statute as judges usually decide cases based on the statutes. In Biobaku v. Police, ${ }^{13}$ Bairamian J. (as he then was) defined the word "corruptly" to mean "improperly" and proceeded to define "improperly" as "the receiving or offering of some benefit as a reward or inducement to sway or deflect the receiver from the honest and impartial discharge of his duties." ${ }^{14}$

\section{Theoretical Framework on Notion of Corruption}

The concept of corruption is a legal, socio-economic and political pattern which is surrounded by varieties of controversy. Some schools of thought of corruption advanced conceptual clarifications on the subject. These schools include the following: Moralists, functionalists, social Censurists, Social Constructionists and Realists.

\subsection{Moralist School}

This group considers "corruption as an immoral and unethical phenomenon that contains a set of moral aberrations from moral standards of society, causing

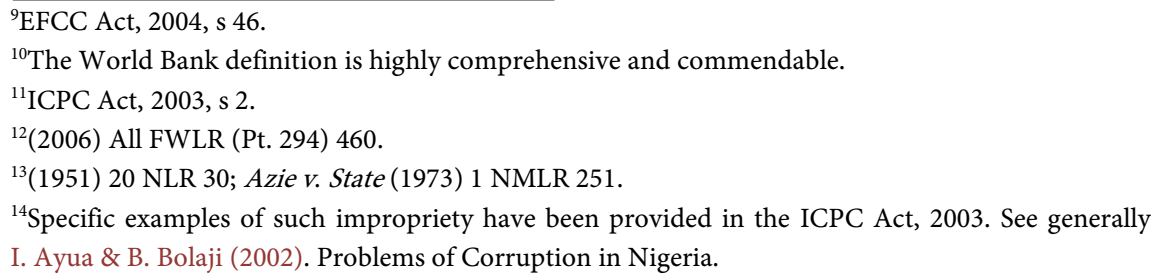


loss of respect for and confidence in duly constituted authority." ${ }^{15}$ One of the proponent of this school is Joseph Nye who defines corruption as "a behaviour that deviates from the formal duties of a public role (elective or appointive) because of private-regarding (personal, close family, private clique) wealth or status gains, or violates rules against the exercises of certain types of private-regarding influences." 16 This school of thought is criticized on the basis that it "tends to individualize a societal phenomenon and attempts to dichotomize as to what is good and what is bad. In the process, societal contexts are ignored and the gap between formal norms and the underlying practice girded norms are not analyzed." ${ }^{17}$

\subsection{Functionalist School}

This school plays the devil's advocate as it views corruption from the benefit perspective. It suggests that corruption can speed up difficult procedures, it can also purchase political access for the privileged, and can produce practical policies in an effective and efficient way in comparative with those emerging from legitimate channels. ${ }^{18}$ The functionalist school is criticized on the plank that it ignores the political significance of deviance and lack any consideration of power, interest and social structure in its analysis and omitted to evaluate the origins of corruption. ${ }^{19}$

\subsection{Social Censure and Social Construction Realists Schools}

These are recent perspective and have diametrically different views on corruption from the functionalists and moralists. They look at corruption from a broad societal perspective. The Social Censure School propounds the view that in understanding corruption one should take into consideration the capacity of the state to produce a particular form of social relations and shift the theoretical emphasis to the interplay of law, ideologies and political economy. ${ }^{20}$ Similarly, the Social Construction Realistic School posits that corruption is problematic and that the perpetrators can be studied by relating them to contextual information on their social positions, interests and stakes in the system as well as on the ${ }^{15}$ J. David \& J.D. Gould (1999). Administrative Corruption: Incidence, Causes, and Remedial Strategies, in Farazmand, A. (1999) Handbook of Comparative and Development in Public Administration. (ed.). New York: Mercel Dekker.

${ }^{16} \mathrm{~J}$. Nye (1957). Corruption and Political Development: A Cost-Benefit Analysis in Ekpo M.U. (1957) Bureaucratic Corruption in Sub-Saharan Africa: Toward a Search for causes and consequences (ed.). Washington DC: University Press of America.

${ }^{17}$ See, Atuobi, S.M. op.cit, 4.

${ }^{18}$ J.R.A. Aye (2002). Political and Social Consequence of Corruption' in Corruption and Development in Africa Proceedings of a Seminar Organized by the Ghana Academy of Arts and Sciences with Friedrich Ebert Foundation.

${ }^{19}$ T. W. Lo (1993). Corruption and Polities in Hong Kong and China. Buckingham: Open University. This school's belief that corruption has some benefits has been challenged with recent experience which has shown the negative effects of corruption. See, generally J. Cartier-Bression. (2004) From the State of the Question to the Question of the State. Cophenhagen: Cophenhagen Consensus Opponent Notes on poor Government and Corruption.

${ }^{20}$ Ibid., 5. 
political, economic and social conditions within which they function. ${ }^{21}$

\subsection{Corruption Syndrome}

This is the latest concept introduced to enhance the understanding of the nature of corruption in different societies. A Corruption syndrome is defined by the political and economic dynamics that a country has experienced and, within these dynamics, how people participate in them and how institutions have been established to define their rules and boundaries. ${ }^{22}$ This considers the nature and level of corruption in different economies and societies. For instance, it believes that advanced democracies with solid political and economic institutions are likely to be different from those countries in transitional stage of democratization and economic reforms. ${ }^{23}$ Similarly, fragile states or countries emerging from conflict with weak political and economic institutions will experience different dynamic of corruption. This dynamics, perhaps explains the high level of corruption in Nigeria and other African States undergoing democratic transition, economic reform or emerging from conflict. ${ }^{24}$

\section{Typology of Corruption}

There has been sundry debate over corruption and its vicissitude from the dividing lines of those condemning it as patently "bad" and those advocating for cultural relativism or real politic pragmatism. ${ }^{25}$ The corrupt character of what is in essence "predation" relates to the reprehensible deviation from a politically legitimate state of affairs, most notably the violation of public duties by private interests when rules or norms objectively define these two realms. ${ }^{26}$ At a conceptual level, deciphering the political consequences of corruption thus requires both a contextualization and a differentiation of the types of corruption involved.

It has been argued that the effects of corruption are not systematically disintegrative or destabilizing and their assessment requires "knowledge of the systems involved and of the extent to which the linkage and divisions fostered by corruption correspond with the more basic fault lines of society". ${ }^{27}$ There are four types of corruption as argued by Johnston in his work. These include: Market Corruption, Patronage Corruption, Nepotism Corruption, and Crisis Corruption-along the line of members of suppliers and the stakes involved. ${ }^{28}$

Market Corruption is a typology of corruption which is both stable and integrative as it involves routine stakes of exchanges and many suppliers dispensing

${ }^{21} \mathrm{~V}$. Pavarala (2010). Interpreting Corruption: Elite Perspectives in India. New Delhi: Sage.

${ }^{22}$ See, USAID (2006). Corruption Assessment. Handbook Washington: Draft Final Report.

${ }^{23}$ Ibid

${ }^{24}$ S. M. Atuobi, op.cit

${ }^{25}$ P. Le Billion (2003). Buying Peace or Fuelling War: The Role of Corruption in Armed Conflicts” J. Int. Deu.

${ }^{26}$ P. Chabal \& J. P. Daloz (1999). Africa Works: Disorder as Political Instrument. Oxford: James Currey.

${ }^{27}$ M. Johnston (1989). The Political Consequences of Corruption: A Reassessment in Comparative Politics.

${ }^{28}$ Ibid. 
corrupt benefits. Patronage Corruption is also integrative and stable as it involves few suppliers but routine stakes concerning large networks. Nepotistic Corruption typology involves extraordinary stakes and a few suppliers within a kinship and friendship network. It is usually disintegrative outside this network and likely unstable. Crisis Corruption involves multiple suppliers and extraordinary stakes and most unstable and disintegrative (Figure 1).

\subsection{Legitimate or Criminal?}

Even though corruption is illegal under global standards of good governance, however, it is often an integral part of some political order and may even be seen as legitimate by a significant proportion of the population. As seen in the typology of Market Corruption, the pervasiveness of corruption in most aspects of daily life and its rewarding of individuals according to a condoned social order positively related to its legitimacy.

In the same vein, the corruption of politics through a system of patron-client relationships guided by private interests can ensure some degree of political stability due to the prevalence of reciprocity among political actors. In Nigeria, such legitimacy is bounded by ties of kinship and community within which redistribution is governed by a logic of patronage. Corrupt behaviour is therefore not only driven by greed and structural forces, but also by informal codes of conduct associated with reciprocity ties within particularistic and communitarian social network. ${ }^{29}$ The legitimacy of corruption is thus bounded by the legitimacy of control over resources; with conflicts arising when this control extends beyond the mutual recognized resources boundaries of social networks or fail rules of reciprocity.

While these codes of conduct do not reflect a universalistic notion of public good, their legitimacy rests on benefits channeled down these networks, outside which non-reciprocal or even predatory relations dominate. The point is not whether corruption is illegal but whether or not it is interpreted as legitimate; that is, within the boundaries of acceptable behaviour for the elite, the military, the business community, or the general population. The obvious questions are thus which people decide upon this legitimacy and how can they be informed of the level and use of corruption to decide upon its acceptability. Social and political identities as well as access to independent media are thus critical issues as demonstrated by the importance of corruption in political rumors circulated through common media. ${ }^{30}$

\subsection{Monopolistic or Competitive?}

The degree of conflictuality associated with corruption is also related to its level of competitiveness. In divided societies, a distribution of the spoils of office among different and possibly antagonistic groups and regions can help to stabilize a

${ }^{29}$ P. Chabel. \& J.P Daloz (supra).

${ }^{30}$ See generally, P. Le Billion (supra) 416. 


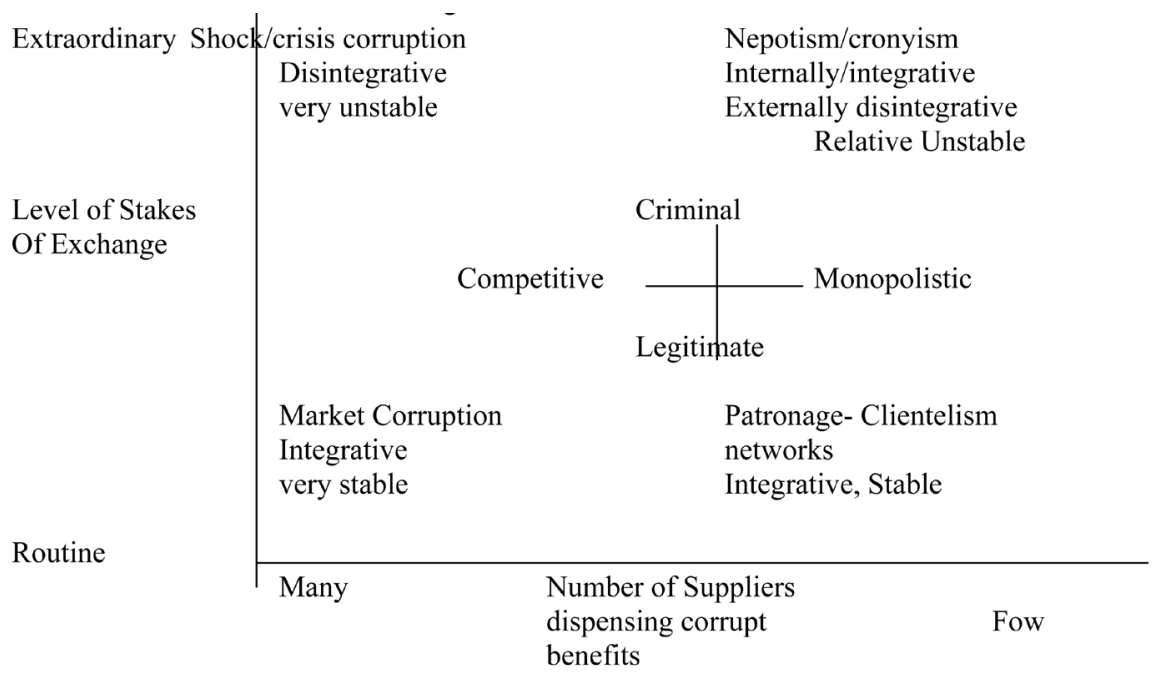

Figure 1. Types of corruption and consequences for political integration and stability adapted from Johnston, 1986.

country's politics and economy. The tacit institutionalization of corruption within the hierarchy of the state apparatus is a powerful means for a ruling group to retain the allegiance of its individual members and organizations by providing both an inescapable economic incentive (access to rents/bribes) and disciplinary threat (dismissal for corruption). Finally, Political corruption provides rulers with a means to channel funds outside through a parallel budget used for political purposes, such a patronage or electoral campaigning, thereby often sustaining a stable political order. ${ }^{31}$

This relation between political corruption and stability is dominated in many democracies by the motivation of businesses to influence politics and the demand of politicians for party funds, giving rise to the creation of corruption networks establishing informal social networks of trust between actors with generally no kinship relations. ${ }^{32}$ Elite schools, cabinet appointments and positions in the headquarters of major corporations assist in developing these networks and reducing competition. In many developing countries, on the contrary, it is informal social networks that are driving corruption, as public actors controlling access to the state rents respond, in part, to the demand of relatives, cronies and clients. ${ }^{33}$ In such cases, the possible lack of institutionalization and the breakdown of patronage regimes increase the risk of competitive corruption. For instance, in Democratic Republic of Congo, ${ }^{34}$ Mobutu SeseSeko sustained a political order largely by a co-opting dissent and buying allegiance through regularly reshuffling lucrative positions in his government, ${ }^{35}$ providing generous cash ${ }^{31}$ Ibid.

${ }^{32}$ J Cartier-Bresson (1998) Les reseaux de corruption et la strategie des trios S: Sleep-Slience-Smile in La Corruption, L' Envers des Droits de L'Homme, Borgi, M, Meyer-Bish P (eds). Fribourg: Editions Universitaries de Fribourg.

${ }^{33}$ J.F. Medard (1998) Le Crise de L'etat neo-patrimonial etl'evolution de la corruption en Afrique Sub-Saharienne: Mondes en Developpement.

${ }^{34}$ Known as Democratic Republic of Congo which Mobutu SeseSeko Kuku NgbenduWaZaBanga renamed Zaire in 1971.

${ }^{35}$ Mobutu SeseSeko reshuffled his government 43 times between 1965 and 1990 . 
handouts from foreign aid and mineral rents, and by the preferential allocation of nationalized foreign businesses. ${ }^{36}$ In Nigeria, Ibrahim BadamosiBabangida replayed the Mobutu style by incessant and constant reshuffling of his cabinet to accommodate prospective dissidents within the rank and file of the military while democratization of corruption was an intentional regime policy calculated to fan allegiance.

While this monopolistic form of corruption initially consolidated Mobutu's power, the erosion of public rents from the mid-1980s onwards and the democratization taking place from 1990 onwards were paralleled by the rise of competitive forms of corruption within his entourage, the administration and the army, leading to the ultimate collapse of his regime under military pressure in $1997.3^{37}$

\section{The Causes of Corruption in Nigeria}

The causes of corruption are myriad in Nigeria; and have both political and cultural variables. Some evidence points to a link between corruption and social diversity, ethno-linguistic fractionalization, and the proportions of country's population adhering to different traditions. ${ }^{38}$ Thus the political system and the culture of the Nigerian society make the citizens more prone to corrupt activities. Johnston noted thus, ${ }^{39}$

corruption is not something that "happens to" otherwise healthy societies: no country has ever been free of it and those that reduce it still confront other problems. Corruption is one of a constellation of interrelated development problems endogenous to societies and the changes they experience. It is not only worrisome in its own right, but also a symptom of deeper difficulties. Thus while it will always be important to attack corrupt behaviour itself, it is critical to understand the broader setting within which it arises, and which it can shape in important ways.

As Seidman explained,

There is not, obviously, any simply cure for endemic corruption. There is no single cause for corrupt motivation. It exists in a wide variety of circumstances: the pressures pointing towards corruption are many and varied. $^{40}$

The fundamental factors that engender corrupt practices in Nigeria include:

${ }^{36}$ KNFEmizet. (2000). Congo (Zaire): Corruption, Disintegration and State Failure, in Weak States and Vulnerable Economies: Humanitarian Emergencies in Developing Countries, NafzigerEW, Stewart F., Vayrynen R (ed.). Oxford: Oxford University Press.

${ }^{37}$ Ibid.

${ }^{38}$ L. S. Martin \& G. S. Lenz (2000). Corruption, Culture and Market, in Culture Matters (ed.). New York: Basic Books.

${ }^{39} \mathrm{R}$. Seidman (1974). Corruption: A Case Study in Deviance in Source Book of Ethiopian Law and Development by Paul Brietzke.

${ }^{40} \mathrm{~N}$. Tony (2017). Price Nigeria is paying for Corruption in V. Dik. Corruption in Nigeria: A New Paradigm for Effective Control, Africa Economic Analysis www.AfricaEconomicAnalysis.org. accessed on 03/10/2017. 
1) Inequality in the distribution of the commonwealth

2) Political position as means of access to wealth

3) Conflict between changing moral code

4) Dysfunctional social and governmental enforcement mechanisms

5) Ethnistic/nepotistic factor and many more.

In Nigeria, obsession with materialism, compulsion for a shortcut to affluence, glorification and approbation (of ill-gotten wealth) by the general public, are among the varied reasons for the persistence of corruption in the country. ${ }^{41}$ It has been noted that one of the popular, but unfortunate indices of good life in Nigeria, is flamboyant affluence and conspicuous consumption. As a result of this, individuals get into dubious activities, including ritual murder for riches. Acquisition of wealth has become a culture in Nigeria and everyone craves for it irrespective of the means, just as the end justifies the means. The traditional culture has internalized the concept of the "big man" marked by ostentatious wealth and numerous clients, retainers and hangers on. ${ }^{42}$ The cultural imperative is that a high-ranking person in the society must assume the role of the "big man" with all its connotations. He must have several dependants; must provide sustenance for them and must own houses and a fleet of vehicles appropriate to the status.

Again, the lack of ethical standards throughout the agencies of government and business organizations in Nigeria is a serious draw back. According to Bowman, ethics is action, the way we practice our values; it is a guidance system to be used in making decisions. The issue of ethics in public sector (and in private life) encompasses a broad range, including a stress on obedience to authority, on the necessity of logic in moral reasoning, and on the necessity of putting moral judgment into practice. ${ }^{43}$ Unfortunately, many office-holders in Nigeria do not have clear conceptions of the ethical demands of their position. Even as corrupt practices are going off the roof, little attention, is given to this ideal.

Additionally, the poor reward system and the penchant for greed add to the basket of corrupt factors in Nigeria. Nigeria operates the poorest reward systems or mechanisms in the world. This is as a result of beclouded national priorities. Hard work is seldom rewarded while rogues are often glorified and deified. The trouble with Nigeria is not that our capacities are in adequate. It is that our priorities, which means our values are wrong, peer community and extended family pressures, and polygamous household are other reasons. ${ }^{44}$ The influence of extended family system and pressure to meet family obligations are more in Nigeria. This requires those in both public service and private sector to channel funds back-home to the less fortunate ones-the more the better as well as ${ }^{41}$ P. Brietzke, (supra).

${ }^{42}$ J. Bowman (1991). Introduction to Ethical Theory and Practice in Public Management' in Ethical Frontier in Public Management: Seeking New Strategies for Resolving Ethical Dilemmas. J. S. Bowman (ed.): San Francisco, Jassey Base.

${ }^{43}$ O. Taiwo \& K. Onalaja (2001). How Polygamy Wrecks Nigeria, Africa: UK, Capwona Books.

${ }^{44}$ The Scoop NG. (2107). 43 Corruption Cases in Court since 2007, <www.thescooping.com> accessed 21 Oct. 2017. 
finding jobs for kinsfolk whether or not they have the required skills or qualifications.

The dysfunctional legal and judicial system lead to people engaging in corrupt behaviour with impunity as surely, they would not be called to account. Culprits are hardly found or brought to book even as corruption flourishes through ostentations wealth and sheer numbers. The legal system and enforcement mechanisms do not have effective and efficient force in both application and outcome. For instance, the Economic and Financial Crimes Commission (EFCC) between 2007 and 2017 has about 43 high profile corruption cases that are still pending in various courts in Nigeria. 16 of those cases involve former governors of states, while others relate to the oil subsidy scandal, money laundering, violation of the public procurement Act and the arms deal case involving Col. Dasuki, former National Security Adviser to President Goodluck Jonathan.

Deep ethnic divisions and conflicts fuel corruption in Nigeria. Ethnic groups jostling for precious administrative and economic positions are usually forced by whatever means possible to gain access to and control over strategic areas of administration and economy. Once in these positions, all methods, legal or otherwise, are employed to ensure that their kinsmen and people have what is referred to in Nigeria as "share of the national cake", irrespective of its fairness or unreasonable. This explains the reason behind the dissection by some leaders to know the ethnic group that occupies certain position in government. The moment the leader realizes that the occupant is of another tribe, he effects a sudden change by way of resufflement or reposting. Employment and contracts are done by virtue of ethnic group or religion.

All these, including bad practices of non-payment or late payment of workers salaries, bad business culture of delays and refusal, or late payment for service executed by business establishment in the country are forms of corruption. Non-payment or late payment of salary is a major corruption provocateur, as public or civil servants who have bills to pay and children to cater for but have diligently done their statutory duties and yet have not been paid will definitely throw ethics and principles to the wind and engage in corrupt practices in order to maintain their families.

\section{Armed Conflict in the Northeast}

Boko Haram emerged as a local Islamic radical Salafist group which transformed into a Salafi-jihadist organization after $2009 .{ }^{45}$ Boko Haram was founded by Yobe state born Muslim Cleric, Mohammed Yusuf in 2002 with its headquarters in maiduguri, Borno State. Boko Haram, is not only opposed to interaction with the western world which it forbids in its teaching, it is also against the muslim establishment and government of Nigeria. In pursuit of their objectives, they initially fought for the establishment of a Sharia government in Borno State under ${ }^{45}$ D. Cook (2014). The Rise of Boko Haram' in HaglerOkorie. Combating Boko Haram Insurgency in Nigeria: The Imperative of Adopting the Mechanism of the Rule of Law, Ife Journal of International and Comparative Law (Vol I No. 2), Ife. 
the regime of Senator Ali Modu Sheriff as Governor. However after 2009, subsequent to the murder of their founder, their aim was directed towards the Islamisation of the entire country-Nigeria. After the killing in police custody of Mohammed Yusuf on July 30, 2009, Boko Haram declared war against the state of Nigeria. The sect carried out monumental and horrendous attacks that shocked the conscience of the world. These attacks resulted in massive and unspeakable fatalities.

In response to the Sect's macabre actions of murder and madness, the Nigeria Security forces typically engaged the policy of "revenge". There was massive state murders and destruction of properties of both Boko Haram members, sympathizers and a motley huge number of innocent civilians. The Nigerian military forces committed various humanitarian law violations, war crimes and acts which constitute crimes against humanity. ${ }^{46}$ Also Military Forces have carried out numerous extra-Judicial executions of suspected Boko Haram members and sympathizers. In many cases arbitrary arrests are made and in many cases the arrests were made without reasonable suspicion or without investigations. Torture and other ill-treatment by the police and security forces were widespread. Demolitions of informal settlements led to the forced eviction of thousands of people. ${ }^{47}$ Boko Haram sect and the Nigerian Military Forces have continued to commit war crimes and crimes against humanity in North-Eastern Nigeria. They have both committed various violations of international humanitarian law and must be held to account for same in order to fight impunity.

The fighting in the North-Eastern Nigeria has reached the threshold of a non-international armed conflict. Non-international armed conflict has been defined as "conflict of armed confrontation occurring within the territory of a single state and in which the armed forces of no other state are engaged against the central government..." ${ }^{\prime 8}$ Again, it has been defined as:

....armed conflicts ... which take place in the territory of a High Contracting Party between its armed forces and dissident armed forces or other organized armed groups which, under responsible command, exercise such control over a part of its territory as to enable them to carry out sustained and concerted military operations... ${ }^{49}$

Also, in 2013, the office of the Prosecutor in International Criminal Court (ICC) determined the fighting in North-East Nigeria to have attained the threshold of non-international armed conflict. Nigeria became a state party to the Rome Statute on 27 September 2001 and as such under the jurisdiction of this ${ }^{46}$ Amnesty International, "Stars on their Shoulders, Blood on their Hands. War Crimes Committed by the Nigerian Military” 3 June 2016 (AFR 44/1657/2016) available from <https://www.annestyorglen/documents/afr44/1657/2016/en> (accessed on 12/08/2017).

${ }^{47}$ Amnesty International, “Annual Report: Nigeria 2016” from <http://www.amnesty.org/en/countries/africa/nigeria/report-nigeria > (accessed on 12/8/2017).

${ }^{48}$ International Institute of Humanitarian Law (2006). The Manual on the Law of Non-International Armed Conflict. San Remo: International Institute of Humanitarian Law.

${ }^{49}$ Additional Protocol II, Art. I. 
court. The court has jurisdiction over crimes allegedly committed by all the parties in the North-East conflict. In a situation of Non-International armed conflict, Nigeria remains bound by its obligations under international humanitarian law and other armed conflict and international human rights treaties.

\subsection{Boko Haram Combat Activities}

Boko Haram atrocities, intensified violence and violations of laws of armed conflict went on crescendo. The sect indiscriminately killed civilians, abducted women and girls, forcibly conscripted young men and boys and destroyed villages, towns and schools. It also tortured, raped and forcefully took girls into marriages. ${ }^{50}$ The sect perpetrated killings, razed and looted homes, businesses, schools, churches, markets and health facilities in Borno, Yobe and Adamawa States. Since 2009, there have been about 6000 civilian deaths perpetrated by Boko Haram. Within the same time, the sect has destroyed at least 211 schools in Borno state alone, and abducted more than 500 women and girls from the Northeast, of which at least over 100 either escaped, were rescued by Security Forces or were released by them. Some abductees suffered other abuses as sexual violence, forced marriage or and force conversion. ${ }^{51}$ In the largest abduction, the sect captured 276 female students from a secondary school in Chibok, BornoState. Out of this figure, 219 school girls are still in captivity. The sect massacred more than 100 male students in BuniYadi and Potiskum, Yobe State. Boko Haram combatants have continued to attack towns and villages without military presence. The sect has frequently rounded up residents, shot those who tried to escape and executed men and boys. It also vandalized any supplies they needed and set fire to peoples' homes, shops and markets as earlier stated. One of the most lethal attacks occurred on 2 July, 2015 when the sect killed in Kukawa town, Borno State. ${ }^{52}$ The sect ordered residents out of their homes and assembled approximately 58 people outside the village heads house. They told the people to lie down on the street and shot them. They set fire on buildings before finally leaving. ${ }^{53}$ Bomb attacks also continued to kill and cause injury to civilians across the North-East Nigeria. They have routinely targeted locations with no military objectives. Since the start of 2015-2016, there have been over 14 bomb attacks which killed over 222 civilians. Young women and girls are used by the sect as suicide bombers in different attacks. ${ }^{54}$ Also cities in Borno and Yobe states have suffered regular bomb attacks. In Maiduguri, a bomb at an abattoir killed at least 12 people on June 2, 2015. Bomb attacks at Baga Road Motor Park

${ }^{50}$ Human Rights Watch (2017). Abuses by Boko Haram, Conduct of Security Forces, International and Political Violence. World Report 2016 from <https://www.hrw.org/world-report/2016> (accessed 12/8/2017).

${ }^{51}$ Human Rights Watch, Ibid; 3.

${ }^{52}$ Amnesty International (2016). Boko Haram: Civilians Continue to be at risk of Human Rights Abuses by Boko Haram and Human Rights Violations by State Security Force. Written statement to the $30^{\text {th }}$ Session of the UN Human Rights Council (14 September-2 October 2016) (AFR $44 / 2428 / 2016)$ of 24 September 2016.

${ }^{53}$ Ibid.

${ }^{54}$ Ibid. 
on 3 and 22 June, 2015 killed at least 16 civilians. On 31 July, 2015, a bomb on a motorized tricycle exploded in traffic near Gamboru Market Maiduguri and at least 4 civilians died in the explosion. ${ }^{55}$ Again, more than 75 civilians were killed in four explosions at a Mosque and viewing centre near Ajilari Cross, Maiduguri on 20 September 2015 and same at Onion Market in Monguno, Borno State. In Damaturu, Yobe State, a bomb killed at least five worshippers celebrating the end of Ramadan on 17 July 2015 and about 17 people died as they queued to enter Damaturu main market. Later on August 25, 2015, a bomb at the central bus station killed about 5 civilians and 8 worshippers inside the Redeemed Church in Potiskum were also killed by a bomb. ${ }^{56}$

Boko Haram used Improvised Explosive Devices (IEDs), including car bombs, and suicide bombers to kill. The sect raided towns and villages in North-East and terrorized civilians and disrupted ordinary people's livelihoods. Some attacks were carried out by just two or three gunmen on a motorcycle, some by hundreds of fighters who shot civilians in the streets and in their homes. In some attacks, the sect quietly entered villages or towns and assassinated specific individuals identified in advance. ${ }^{57}$ On 6 August, 2014, Boko Haram attacked Gwoza, Borno State. They overran the 350 soldiers stationed in Gwoza and killed at least 600 civilians Thousand of residents fled Gwoza and hid for several days in nearby mountains, waiting for the sect to leave. However, instead of leaving, over the following day, Boko Haram hunted down and executed people they found hiding in the mountains. ${ }^{58}$

\subsection{Corruption and Armed Conflict in the Northeast Nigeria}

One of the major causes of the armed conflict in the Northeast is corruption and its kindred causative chain. The causative chain of armed conflict in the Northeast are corruption, unemployment, poverty, poor government, weak judiciary, socio-economic inequalities, ethno-religious crises and many more. ${ }^{59}$ A Critical appraisal of this causative chain reveals that corruption encapsulates all of them as the major cause of these factors is corruption in general terms.

Unemployment is the inability to be engaged in gainful work and lacking the basic necessities of life. The direct cause of unemployment in the Northeast is corruption. This is because the leadership of the country diverts the state resources allocated for industries and infrastructure into personal accounts abroad. Again, there is no access to education for the young people and as a result many are brainwashed into believing anything they were told by few privileged persons in their midst. Unemployment leads to frustration and frustration invites discontent and conflict. Many unemployed youths in this region have 
become preys to terrorists and have been radicalized. The result is the venting of their anger on the state who has failed to provide job for them. Boko Haram militants lure these youths with money which they cannot resist. As a result of illiteracy, Boko Haram leaders taught them that education is a sin. This development has multiplied the number of unemployed youths roaming the streets and become easy tools for violence in that region. ${ }^{60}$

Another kindred of corruption is poverty. According to World Bank, ${ }^{61}$ the various dimensions of poverty include: lack of opportunity, lack of empowerment and lack of security. The window of opportunity remains closed to the poor masses in the Northeast, and this makes them practically inactive. It also limits their choices in almost everything and their lack of security makes them vulnerable to disease, violence and death. Poverty depicts lack of food, cloths, education and basic amenities of life.

In the Northeast Nigeria, due to poverty, youths have been denied choices and opportunities to get good education, medicare, decent accommodation, lack of land for agriculture, jobs to earn a living and exclusion from normal everyday living. As a result of these lack and want, the youth enlist into Boko Haram membership and turn their anger on the state. When there exist wide gap between the rich and the poor, there comes a breaking-point where there is bound to be a class conflict that materializes in form of revolution as witness today in the Northeast. ${ }^{62}$

Boko Haram criticized the high level of corruption and "Western Orientation" officials causing economic hardship in the country. This belief was confirmed by Harnischfeger who stated that "Poverty, high unemployment rates and overall socio-economic situation of the region" as the reason for Boko Haram rebellion in the Northeast. ${ }^{63}$ The question of poverty is mostly connected to the governmental corruption and mismanagement of the commonwealth of the state and region, as well. Therefore, the membership of Boko Haram who are mostly poor and indigent, join its ranks in the hope for economic and social justice. ${ }^{64}$ The emergence of Boko Haram and its offensive against the state is seeking social justice through the establishment of new, non-corrupt and Islamic government. $^{65}$

During Yusuf Mohammed's reign as the supreme leader of Boko Haram, the first clash occurred when he attacked local Muslim community-Ulema-as a reaction to their close relationship with Governor Sheriff who was described by ${ }^{60}$ J. Odumakin. (2012) Woman of the Sun, in C. M. Tella (supra).

${ }^{61}$ World Bank Report, 2015/2016.

${ }^{62} \mathrm{~T}$. Adetiloye (2014). The Root Cause of Boko Haram And Other Insurgent Groups in Nigeria. Sahara Reporters. (April 21, 2014)

${ }^{63}$ H. Johannes. (2014). Boko Haram and its Muslim Critics: Observations from Yobe State in Boko Haram Islamism, Politics, Security and the State in Nigeria in Marc-Antoine Perouse de Montclos (ed) (Leiden, African Studies Centre, 2014).

${ }^{64}$ A. D. Egiegba. (2013). Living in Fear: Religions Identity, Relative Deprivation and the Boko Haram Terrorism. African Security. (Vol. 6, No. 2). <http://dx.doi.org/10.1080/19392206.2013.788410>.

${ }^{65}$ O. Oarhe. (2013) Boko Haram Insurgency in Northern Nigeria and the Vicious Circle of Internal Conflict. Small Wars and Insurgencies. (Vol. 24, No. 3). 
the sect as running predatory and corrupt governmental policies. ${ }^{66}$ Such claims are supported by international Non-Governmental Organizations such as Transparency International, which ranks Nigeria $136^{\text {th }}$ out of 176 in Corruption Measurement tools and confirms that over $90 \%$ of the population of Nigeria thinks that the governmental and its security forces are corrupt, while $45 \%$ assumes the same about the military and other agencies of government. ${ }^{67}$

\subsection{Almajiri and Poverty in North East Nigeria}

Almajiri is derived from the Arabic word "Al-Muhaajirun," which is by inference, a learned Ulama who propagates the peaceful course of Islam. But the Almajiri concept has since outlived its purposes in Nigeria and has become a breeding ground for child begging and potential terrorist's camps in Nigeria. The pupils who are meant to be trained to emerge as Ulumas have had to struggle to cater for themselves through begging rather than learning under the watch of the semi-literate Quranic teacher or Mallams who themselves lack the requisite support, and use the system as a means of living rather than a way of life. The Almajiri system typifies child abuse, social exclusion and chronic poverty by kleptomatic corruption orchestrated by politicians and other public officers in Nigeria. ${ }^{68}$

The National Council for the Welfare of Destitute puts the current population of the Almajiri $s$ at about 7 million. ${ }^{69}$ This outrageous figure is indicative of the abdication of duty and care by both government and parents of these kids. AImajiri' $s$ occupy virtually all the nooks and crannies of the Northern States of Nigeria. ${ }^{70}$ The Almajiri $s$ are sent off mostly from rural areas by their illiterate parent between the ages of $6-12$ years to the cities without provision to study Holy Quran, under harsh and despicable conditions. Apart from roaming the streets with cups and begging for alms while dressed in rags, scavenging on food remnants, the children are involved in various types of work and live under bridges, motor parks, mosques, market stalls and so on. ${ }^{71}$ These are the ready materials for recruitment by Boko Haram.

As can be gleamed from the foregoing discussion, corruption which bred poverty especially in the Northeast triggered the present day armed conflict between Boko Haram and the Federal Forces of Nigeria. This is because the state of Nigeria created misery and frustration among the people which pushed them into revolution against the state. This is true as Boko Haram at the outset domiciled its operational base at the poorest part of Northern Nigeria. It is in such ${ }^{66}$ M. Kyari (2010). The Message and Methods of Boko Haram," in Boko Haram, Islamism, Politics, Security and the State of Nigeria (supra).

${ }^{67}$ Transparency International. (2016). Nigeria: Corruption and Insecurity

$<$ http://www.transparency.org/news/feature/nigeria_corruption_and_insecurity $>$.

${ }^{68} \mathrm{Ra}$-ah International Development. (2014). Almajiri Project in Northern Nigeria, in Gabriel Ngbea and Hillary Achunike, "Poverty in Northern Nigeria. Asian Journal of Humanities and Social Studies. (Vol. 2).

${ }^{69}$ Ibid.

${ }^{70}$ I. A. Abdulqadir. (2013) The Almajiri System of Education in Nigeria Today <http://www.gamji.co/articles5000/news5956.htm> retrieved 11/11/2017.

${ }^{71}$ M. Bala. (2013, June 29). Almajiri: A Memo to the Sultan. Weekly Trust Newspaper. 
places where people have been denied opportunity for education, meaningful economic sources of livelihood that recruitment is the easiest. When a young man is poor, illiterate and unemployed, he becomes a ready vessel for every kind of brainwashing. The brainwashing will include the fact that politicians and their apologists are corrupt and evil as they selfishly scavenge on the commonwealth of the people. The brainwashing will include a quote from the Holy Quran that such people are condemned to death. They are then commissioned to kill such "infidel" and have their reward in paradise. ${ }^{72}$ From the scenario painted above, it is at this point indubitable that one of the major root causes of the armed conflict in the Northeast Nigeria is corruption perpetrated by the leadership in $\mathrm{Ni}$ geria.

\section{Corruption and Other Situations of Violence (OSVs) in Nigeria}

The term in "OSVs" is used to categorize conflicts that did not get to the threshold of an armed conflict. The state of Nigeria has witnessed various versions of conflict in which the root cause is traceable to corruption by the leadership in the country. OSVs take the form of civil disorder which include civil unrest or civil strife caused by a group of people. Typically, a non-international armed conflict refers to a situation of violence involving protracted armed confrontations between governmental forces or more organized armed groups, or between such groups themselves, arising on the territory of a state. ${ }^{73}$ The existence of a non-international armed conflict triggers the application of international humanitarian law (IHL), also known as the law of armed conflict, which sets limits on how the parties may conduct hostilities and protects all persons affected by the conflict. IHL requires that two criteria must be met for there to be a non-international armed conflict:

1) The armed groups involved must show a minimum degree of organization

2) The armed confrontations must reach a minimum level of intensity.

A non-international armed conflict is distinguished from lesser forms of collective violence such as civil unrest, riots, isolated acts of terrorism or other sporadic acts of violence. ${ }^{74}$ Civil disturbance is a symptom of and a form of protest against major socio-economic and political problems in the society.

Nigeria is a nation of approximately 180 Million people and also has about 250 ethnic groups and languages. From independence through military regime and to democratic governments, Nigeria has been a scene of frequent civil unrest and disturbances. Most of which root causes are attributable to corruptive tendencies parading within the clime. Between 1960 and 1966, the Nigerian political elite of the Nigeria Peoples' Congress (NPC), National Council of Nigerian Citi${ }^{72}$ A. Olufemi. (2012). Boko Haram and Poverty in Northern Nigeria <http://www.punchng.com/opinion/bokoharam-and-poverty-in-northern-Nigeria $>$ Retrieved 11/11/2017.

${ }^{73}$ K. Lawande (2012). Internal conflicts or Other Situations of Violence-What is the Difference for Victims. ICRC Interview.

${ }^{74}$ Additional Protocol to the Geneva Convention of 12 August, 1949 and Relating to the Protection of Victims of Non-international Armed Conflict of 8 June, 1977 (APII), Art. 1(2). 
zens (NCNC), and the Action Group (AG) were able to diversify their activities into new, often dubious and fraudulent forms of primitive accumulation of wealth at public expense. These forms include the fraudulent award (including outright sale) of unsecured government loans, produce buying and import-license to their cronies, the inflation of government contract values (and the consequential enlargement of payable "kickbacks" to themselves) and the straight forward looting of the treasury by their major political acolytes and group that dominated the polities of the First Republic. The aim was to monopolize and have the lion share of the loot from the systematic plundering of the commonwealth of Nigeria. ${ }^{75}$ This was the major motivation which resulted in the high intensity and bitterness that heralded the contest for political power along ethno-regional lines which led to the following crises and conflicts:

1) Action Group Crisis of 1962

2) Census Crisis of 1962-1963

3) Federal Election Crisis of 1965,

These conflicts resulted in the January $15^{\text {th }}, 1966$ Military Coup $d^{\text {e etat led by }}$ Major Kaduna Nzeogwu. The mission of this coup was to end misrule, corruption and ineptitude that pervaded in that era. After the first Kaduna Nzeogwu's military coup, the successive coup $d$ etates also hinged their reason for incursion into the governance arena to corruption and the gradual slide into kleptocracy as perpetrated by removed government.

Violence in Nigeria in its various forms has evolved over the decades; from use of traditional weapons, charms and amulets, violence in Nigeria has taken sophisticated dimension. Political, electoral, religious, ethnic/tribal, cultism and other forms of violence are dominant in the Nigeria society at varying degrees. Each region in Nigeria has its peculiarity. Over again, violence has threatened the peace, stability and unity of Nigeria. Other situations of violence in Nigeria to be discussed include:

1) The Niger Delta Militancy;

2) The Indigenous Peoples of Biafra's secessionist movement; and

3) The Fulani herdsman attacks.

\subsection{The Niger Delta Militancy}

The current conflict in the Niger Delta first arose in the early 1990s over tensions between foreign oil corporations and a number of the Niger Delta's minority ethnic groups who feel they are being exploited, particularly the Ogoni and the Ijaw. Ethnic and political unrest has continued throughout the 1990s despite the coming on board of democratic regime in 1999. The Competition for oil wealth has fueled violence between ethnic groups, causing the militarization of nearly the entire region by ethnic militia groups, Nigerian Military and Nigerian Mobile Police. ${ }^{76}$ The Niger Delta has earned the Nigerian government billions of ${ }^{75}$ E. Austine, M. Voke \& A. Okiemute (2013). Corruption in Nigeria: A Historical Perspective. Research on Humanitarian and Social Sciences (Vol. 3, No. 16).

${ }^{76} \mathrm{~K}$. Carlo (2015). The Effects of Oil Production and Ethnic Representation on Violent Conflict in Nigeria: A Mixed Methods Approach in Terrorism and Political Violence. 
dollars; yet the communities in that region continue to live in abject poverty. Nigeria, after nearly five decades of oil production, had by the early 1980's become almost completely economically dependent on petroleum extraction, which at the time generated 25\% of its GDP. This position has since risen to $60 \%$ as at 2016. Despite the vast wealth created by petroleum, the benefits have been slow to trickle down to the majority of the population, who since have increasingly been forced to abandon their traditional agricultural practices.

Oil drilling in Nigeria began in 1950s and since that time Nigeria become the Worlds tenth largest oil exporter. The abundant oil reserves resulted in widespread exploitation. The Niger Delta region encompasses about $8 \%$ of Nigeria's landmass and is the largest wetland region on the African continent. ${ }^{77}$ In the beginning, the oil drilling in that region stimulated Nigeria's economy and was extremely beneficial to the country. Numerous multinational corporations established oil operations there and made conscious efforts not to violate any environmental or human rights regulations. Shell began drilling in the Niger Delta region in 1956. Shell's presence in Nigeria has been detrimental to the people. ${ }^{78}$ The negative consequences to the people of that region are the result of thousands of oil spills, human rights violations, environmental destruction and monumental corruption. Over the past half century, Nigeria has become a plutocratic state where political power is solely in the hands of the socio-economic elite and public officials who plundered the commonwealth of the Niger-Delta region. According to the documentary "Poison Fire", one and a half million tons of oil has been discharged into the Delta's farms, forest, and rivers since oil drilling began in 1956. Again, hundreds of kilometers of rain forest have been destroyed by the oil spills. When petroleum is discharged into the soil, the soil becomes acidic, which disrupts photosynthesis and kills trees because their roots are not able to get oxygen. Moreover, the fish population has also been negatively affected by the oil drilling.

Land and water have been polluted by oil spills and their air ruined by constant burning off of natural gas. In the words of Alex Last:

There is an apocryphal story often told about the origin of the disquiet in the Delta. In the 1990s, the then military ruler, SaniAbacha, invited people from the Delta to the new purpose-built capital, Abuja. When they saw its huge, well-ordered roads, bridges and high-rise buildings, they realized what the oil money could do, and allow little of it they saw. And so the trouble began. ${ }^{79}$

The last account of the origin of the militancy in the Niger Delta is persuasive. In any case, whatever is the precise genesis of the conflict and violence in that region, the important factor is that economic prosperity in Nigeria is largely dependent on the happening there and there should be reflection or corresponding

${ }^{77}$ A. Pigrau (2013). The Environmental and Social Impact of Shell's Operations in Nigeria. Per La Pau/Peace in Progress International Catalan Institute for Peace.

${ }^{78}$ Ibid.

${ }^{79}$ A. Last (2006, February 11). Nigeria’s Oil Hope and Despair. BBC News. 
development and well-being on the lives of the inhabitants and population of that region. The violence generated in the Niger Delta is a function of the level of abandonment by both the federation of Nigeria and its leadership and the oil corporations operating in that region. In defence of their environment and rights to life and decent living, the following militant groups took up arms against the state and the oil corporations:

1) Niger Delta Peoples' Volunteer Force led by Mujahid Dokubo-Asari

2) Niger Delta Vigilantes led by Ateke Tom

3) Movement for the Emancipation of the Niger Delta led by Henry Okah

4) Niger Delta Avengers led by Government Ekpemupolo also known as Tompolo

It must be noted that the motive behind the formation of various militant groups in this region is the inability of the State of Nigeria to deliver to the people of Niger Delta the most basic services, to meet vital development needs, and the high-handedness of the state forces unleashed to combat the violence/conflict. The Niger Delta region is a paradox of poverty and underdevelopment in the mist of plenty. This is because in spite of oil wealth in the region, it still remains one of the least developed parts of Nigeria characterized by widespread poverty ${ }^{80}$ It is the deep rooted sense of neglect and marginalization by the government in providing or supporting critical human development and provision of basic social amenities that underlay the persistent militancy in this region. Importantly, the functional motive for militancy is the crass level of corruption perpetrated by the leadership of both the states in the region and Federal government in the financial and prudent allocation and management of the fiscal resources or proceeds from oil and gas drilling and sale. This position was accentuated by NdomaEgba when he posits that the inability of the Nigerian State to address the development needs of the region has led to the persistent agitation and violent crisis in the region. ${ }^{81}$ This inability is expressed within the framework of the level of corruption pervading in the oil industry and government agencies established to serve as regulatory bodies for oil exploration, exploitation, exportation, use and sale in Nigeria.

Clearly, the Niger Delta militancy is a consequence of monumental corruption found in the state agencies with reference to their inability or unwillingness to provide basic development needs of the people of the region. This found expression in the looting of public funds found during various successive governments in Nigeria since independence. However, the plundering were more during the military regimes of General Ibrahim BadamosiBabangida and General SaniAbacha. The lootocracy found restatement during the return of civilian regime in 1999 until today. Today, Niger Delta is still left in the lurch. It must be noted that several huge financial allocations have been voted to address the develop${ }^{80}$ S. Ogege (2011). Amnesty Initiative and the Dilemma of Sustainable Development in the Niger Delta Region of Nigeria. Journal of Sustainable Development, Vol. 4, No. 4.

${ }^{81}$ N. Egba (2004). Forced Unity: The Nationality Question in O.E. Uya (ed), Civil Society and the Consolidation of Democracy in Nigeria, being proceeding of IPPA International Seminar held at Chinua Achebe New Arts Theatre, University of Calabar, From 25-26 ${ }^{\text {th }}$ May 2000. 
ment needs to the region. These financial allocations have been voted through the Oil Mineral Producing Areas Development Commission (OMPADEC) created in 1993 by the Military Regime of General Ibrahim Babangida, the Niger Delta Development Commission (NDDC) established in 2000 by the civilian regime of Chief OlusegunObasanjo and the Ministry of Niger Delta created in 2008 by AlhajiUmaru Musa Yaradua's government. Their sole mandate was to develop the region by addressing all the challenges evident in the region.

The existence of these institutions and agencies and the huge financial allocations given to them have not translated to any visible development and truthfully, corruption and general poor political leadership is to blame. ${ }^{82}$ Nigerian under-development, including under development in the Niger Delta, is a consequence of bad leadership characterized by corruption and perbendalism. Also involved in the corruption complicity and conspiracy are the political leaders of the Niger Delta States. The 13\% derivation fund, the statutory allocations from the Federation Account and the internally generated revenue (IGR) received by these oil states in this region were looted and diverted by these political leaders. ${ }^{83}$

The Niger Delta militancy is a function and consequence of failure of Nigeria state to deliver basic services and development to the region as a result of monumental corruption festering around state and Federal government and other agencies of the state.

\subsection{Indigenous Peoples of Biafra (IPOB)}

The IPOB is a separatist organization led by NnamdiKanu. The group wants a number of states in the Southeast which is principally made up of people from Ibo ethnic group, to break away from Nigeria and form the independent nation of Biafra. To achieve this, the group is calling for a referendum. The group also engages intimidation and sometimes violence on civilians who oppose their agenda and modus operandi. The group's methodology include: sit-at-home, blocking of major roads in the southeast, formation of security organization or outfit and establishment of guards to protect their leaders against the state. They also organize rallies and marches around the Southeast region. Members of the public who encounter them are expected to comply, as refusal will be met with manhandling and other negative consequences and harm.

IPOB leadership has given reasons why it will continue the agitation for Biafra. It states that:

"it was to end the unnecessary rampage and destruction of farmlands and

\footnotetext{
${ }^{82}$ A. Olite \& N. Umuokoro (2011). Amnesty Programme and the Niger Delta: Overview of Disarmament Demobilization and Re-integration Strategy for Sustainable Peace in Nigeria. Special Issues, Vol. 5 No. 1.

${ }^{83}$ DiepreyeAlamiesiegha, former Governor of Bayelsa State was convicted for stealing huge sum from the state; James Iboru, former Governor of Delta State was convicted for stealing and money laundering of state funds; Timipre Sylva, former Governor of Bayelsa State and Lucky Igbinedion, former Governor of Edo State were both accused of stealing and laundering of state funds, Tell Magazine, "50 years of Oil in Nigeria," (2008), Feb. 18. Also, Peter Odili and RotomiAmaechi both former Governors of Rivers State have been accused of stealing and diversion of state funds.
} 
crops in the region; to end the unprovoked killings of our people; to avoid harassment and attacks from the military; to improve the education and judicial sector; to end marginalization of the people of the region."

The successive governments of this country have paid service to infrastructural development in the southeast. All the Federal roads in that region are highly impassable. The Ibo man is an industrious businessman or trader that requires motorable roads to convey his goods and commute from one city to another. The total neglect of the Federal roads network across the region has caused untold hardship to the people. Similarly, electricity, tertiary institutions, Airports and political appointments are other areas that have thrown-up debates of marginalization against the region.

The Federal roads in the Southeast have been awarded at different times by various governments both civilian and military. However, the construction companies mobilize to location only to vacate their equipment after a short period of time. These contractors collect mobilization fees and other fees, only to abandon the project without completion. These are the experiences at Enugu-Port Harcourt, Enugu-Onitsha, Umuahia-IkotEkpene, Aba-IkotEkpene, and many others. The major challenge is the inability of the supervisory government agency to monitor the level of execution of these jobs. It is however, believed that staff of such agency conspire and collude with these contractors in this regard as they are paid rents. Therefore, it is not that the roads were not awarded but that rents and corruption took the better part of government officials assigned to supervise and oversee the execution of the projects.

In another development, the various political leaders in the states that make up southeast region, have failed in their responsibility towards their people. From military regime to civilian regime the monumental dilapidation, degradation and despoliation of the region can only be attributable to ineptitude and personal Self aggrandizement, especially, the civilian Governors who are also Ndigbo by birth and creed. Since 1999 the people of the region have elected different sons and daughters as Governors, House of Assembly members, Senators, House of Representatives members and yet these challenges were not tackled or addressed by them. This is a demonstration of self-service and greed. The political leaders in the southeast especially the Governors that managed the region's commonwealth which includes: Federal allocations, excess crude allocation, ecological funds, Paris Club refund, bail-out funds, World Bank and IMF intervention funds, bonds, loans and internally generated revenue, deployed the sundry monies into nowhere discernable. ${ }^{84}$ These colossal economic failures on the

${ }^{84}$ Orji UzorKalu has been charged to court by the Economic and Financial Crimes commission (EFCC) for Stealing, diversion of public funds, money laundering (former governor of Abia State); ChimarokeNanmanni was indicted by EFCC for stealing and diversion of public funds of Enugu State; Sam Egwu and Martin Elechi (both Former Governors of Ebonyi Stat) were also indicted by EFCC for corruption; IkediOhakim (former Governor of Imo State was accused of misappropriation and fraud N18 billion bond loans obtained on behalf of Imo State and N1 billion withdrawals from the State accounts; Chris Ngige (Former Governor of Anambra State) was accused of misappropriation of Local Government funds while he was Governor. 
part of these leaders of the region are principally one of the reasons for the IPOB clamour.

\subsection{Fulani Herdsmen}

Nigeria has 22 million cows that consume about 1 billion gallons of water daily and 500 million kilograms of grass and forage crops. ${ }^{85}$ The stock value of Nigeria's cattle population is about N3.4 trillion or $\$ 16.2$ billion at $\mathrm{N} 150,000$ per cattle. Since there is no commercial ranching in Nigeria, these significant nutritional needs are met through nomadic foraging activities by Fulani herdsmen who roam the country with their cattle, following natural water ways and foraging reserves. Although Nigeria's cattle is a key part of its food security, events which have occurred over the last five years have strained the relationships between nomadic herdsmen and the communities situated on the grazing routes followed by the herdsmen. Nigeria's cattle populations have been the cause of intensifying insecurity and gruesome conflicts.

The root causes of the conflicts stem from three factors that has combined to exacerbate the resource challenges imposed by Nigeria's bourgeoning cattle population. These factors are:

1) Climate Change;

2) Boko Haram Crisis; and

3) Federal Government lack of Political will.

For decades, climate change has slowly changed the landscape of northern Nigeria. Much of the far north has been inundated by desertification. The northern tip of the foraging grounds of Nigeria's cattle has disappeared. Watering grounds are disappearing too. Lake Chad, once a massive oasis in the Northeast has lost about $95 \%$ of its volume over the last 50 years. ${ }^{86}$

Again, for about six years, Boko Haram insurgency has had a profound impact on the Northeast Nigeria's belt. As the sect rampaged through the northeast, it decimated communities and spread insecurity across the region. Cattle rustling increased, millions of people were displaced from their communities, farmlands were abandoned, and a land mass that is almost $15 \%$ of Nigeria, has essentially become a no-go area for nomadic herdsmen. The Northeastern region of Nigeria has some of the richest foraging stock in the country, and much of that is no longer available for use, because of the Boko Haram conflict.

The result of the above scenario is the downward, southwards movement by nomadic Fulani herdsmen as they move in search of water and foraging resources for their cows. This has led to intensification of resource pressures on North Central and Southern communities, culminating in violent struggles that have led to an estimated 8000 deaths since 2009. Indiscriminate cattle grazing has also contributed to the destruction of vegetation and wildlife habitats, and

${ }^{85}$ M. Fabiyi \& A. Otunuga (2016, June 03). Why the Fulani Herdsmen and Farmers Fight: How Climate Change and the Boko Haram Crisis Created the Crisis and Six (6) Evidence-Based Policy Recommendations for its Resolution. Sahara Reporters.

${ }^{86}$ Ibid. 
led to the pollution of farms, rivers and waterways with cattle manure across many communities. Today, Fulani herdsmen conflicts accounted for more deaths that Boko Haram and Niger Delta Militancy put together. ${ }^{87}$

Even though Fulani herdsmen conflicts are now more deadly and represents a more pressing issue the Federal Government of Nigeria has maintained a "conspiratorial criminal silence" on the matter. There have been successive timelines for this macabre-dance of death by the Fulani herdsmen. They struck in Southern Kaduna with over 200 people dead; in Enugu State, particularly at Ukpabi, Nimbo in UzoUwani Local Government, over 40 people were slain by the rampaging herdsmen; in Benue State, over 50 innocent civilians have been butchered in several communities in BurukuKwande, Agatu, Giver East, Giver West, Guma and Gboko, the worst hit has been Buruku and Kwande local government areas with over 30,000 persons displaced and properties and livelihoods worth billions of naira destroyed. ${ }^{88}$ These attacks have been incessant, predictable and preventable if security agencies have lived up to their duties and if the Federal Government has responded swiftly. In spite of the unprovoked blood bath on the lives of the innocent, no herdsmen has been apprehended by the security agencies for questioning as a way to unravel the mystery behind the killings. No single person has been investigated or prosecuted for the attacks and killings even where some persons have come forward claiming prior knowledge and presumed responsibility for the attacks. ${ }^{89}$

The President of the Federal Republic of Nigeria, MuhammaduBuhari, who incidentally is also Fulani and life Patron of Miyetti Allah Cattle Breeders Association (MACBAN), has remained silent on the serial slaughter by these Fulani marauders. As the commander-in-Chief of the Armed Forces of the Federal Republic of Nigeria, he owes Nigerians irrespective of tribe, religion and creed, equal protection and guidance. He owes obedience and respect to the constitution of the country and to the people of Nigeria regardless of tongue and tribe. The Federal Government penchant of "non-intervention" is characteristics of nepotic-clannishness and jingoism which is tantamount to crass corruption of a savagery nature. Indeed, nepotism is the worst type of corruption as it exudes from the spirit and mind of the practitioner. It is more grievous and destructive than financial corruption. This is because a nepotic person discriminates against a fellow human being and regards him as less human while the other type of corruption target things (matter) other than human beings.

\section{Legal Instruments against Corruption in Nigeria}

The following are analysis of some efforts in specific terms towards combating ${ }^{87}$ Y. Kazeem (2017, January 19). Nigeria Now has a Bigger Internal Security Threat than Boko Haram. Quartz Africa.

${ }^{88}$ S. Opejobi. (2017, March 17). Benue: Fulani Herdsmen have killed over 500 and 300,000 displaced. Daily Post.

${ }^{89}$ Ibid. For instance, the head of the herdsmen in Agatu Community showed up and bragged about the killing in March 2016. The Tiv, Idoma and other ethnic groups living in Benue State regarded it as attempted genocide on them. 
corruption and other economic crimes through legislation and establishment of regulating institutions.

1) Advance Fee Fraud and other Related Offences Act. ${ }^{90}$

This Act defines "false pretence" as "a representation, whether deliberate, made by words, in writing or by conduct, of a matter of fact or law, either past or present, which it represents is false in fact or law, and which the person making it knows to be false or does not believe to be true". ${ }^{91}$

2) Banking and Other Financial Institution Act. ${ }^{92}$

This Act was enacted for the purposes of addressing systematic bank frauds and other financial malpractices. The task of realizing this objective was assigned to Hon. Justice C.AOputa (Rtd)'s Committee on Bank Frauds and other Financial Malpractices.

3) Bank Employees, etc. (Declaration of Assets) Act. ${ }^{93}$

This Act is encompassing and defines Bank to include Central Bank of Nigeria, Commercial Banks, Merchant Banks, Acceptance Houses, Discount Houses, Financial Institutions or any other authorized dealer appointed under the Foreign Exchange (Monitoring and Miscellaneous Provisions) Act. ${ }^{94}$ This Omnibus definition provided by this Act eliminates or reduces the possibility of perpetrators of economic crime escaping through an interpretative loophole.

4) Failed Banks (Recovery of Debts) and Financial Malpractices in Banks Act. ${ }^{95}$

The incidences of incessant failed banks in the history of Nigerian banking sector became disturbing and the Act came into effect in order to introduce reforms aimed at making positive sure that banks are sound and healthy. The incidences of failed banks were as a result of malpractices in banks and other economic crime. The Act was tailored to address this issue.

5) Money Laundering (Prohibition) Act 2011. This Act was enacted to correct the perceived inadequacies of the previous laws. ${ }^{96}$ The present Act, among other things, put the duty on the banks to prevent the use of its facilities for money laundering by establishing the identity of its customers through laid down criteria before entering into business with him or her. ${ }^{97}$ The Act also puts a duty on banks to have good knowledge of the customer through the information supplied on him or her known as KYC, that is, know your customer. ${ }^{98}$ Generally, the ${ }^{90}$ The Act currently in force is the Advance Fee Fraud and other Related Offences Act which came into force on $5^{\text {th }}$ June 2006.

${ }^{91} \mathrm{~S} 17$ of the Act. See Amachree V. Nigerian Army (2003) 3 NWLR (Pt. 807) 202-203. On whether stealing is an ingredient of the offense of obtaining by false pretences, the court of Appeal stated: "In proving a charge under section 421 of the Criminal Code, it is not necessary to show that the goods were obtained under circumstances amounting to stealing".

${ }^{92}$ CAP B3, LFN 2004.

${ }^{93}$ CAP BI, LFN 2004.

${ }^{94}$ Section 14 of the Act.

${ }^{95}$ CAP F@, LFN 2004.

${ }^{96} \mathrm{~S} 14$ of the Acts of 1993, 2003 and 2004 whose apparent ineffectiveness necessitated the need for an Amendment.

${ }^{97}$ Ss 3 and 7 of the Act, 2011 Act No. 11.

${ }^{98}$ E. Ugwu. (2006, September 6). Nigeria Delisting From FATF List: The Gains and Challenges for Banks. The Guardian. 
Act makes provisions and for the prevention and punishment of money laundering to regulate over the counter exchange transactions. According to this Act, banks have a duty to exercise utmost diligence in their daily transactions with the customers in order to eliminate the possibility of a customer using the bank in question as a means of money laundering. The aim is to check suspicious transactions. ${ }^{99}$

Pursuant to the above aim, the Act provides for a limitation of the amount of cash payment. Except in a transaction through a financial institution, no person shall make or accept cash payment of a sum greater than that stipulated in the Act. ${ }^{100}$ Again, the bank has or duty to report international transfers of fund and securities. A transfer to or from a foreign country of funds or securities of a sum greater than that stipulated in the Act shall be reported to the Central Bank of Nigeria. ${ }^{101}$ Any report made shall indicate the nature and amount transferred the names and addresses of the sender and receiver of the funds. ${ }^{102}$ It must stated that by virtue of the provisions of this Act, the customary relationship of trust between banks and their customers has come under fire. This demonstrates the desperation of the draftmen to check the level of corruption and economic crime with particular reference to money laundering. Thus from this perspective, certain privileges of bank customers have been sacrificed in the interest of national security. ${ }^{103}$

6) Code of Conduct Bureau and Tribunal Act. ${ }^{104}$

The aims and objectives for the creation are to establish and maintain high standards of morality in the conduct of government business and to ensure that the actions and behaviour of officers conform to the highest standards of public morality and accountability. ${ }^{105}$ This Act is particularly concerned with the public sector which holds most of the government funds. The statutory functions of the Bureau include the following:

a) to receive assets declarations by public officers in accordance with the provisions of the Act;

b) to examine the assets declarations and ensure that they comply with the requirements of the Act and any law for the time being in force.

c) to take and retain custody of such assets and declarations, and

d) to receive complaints about non-compliance with or breach of this Act and where the Bureau considers it necessary to do so, refer such complaint to the Code of Conduct Tribunal established by Section 20 of the Act in accordance with the provisions of Sections 20 to 25 of the Act. ${ }^{106}$

However, where a person concerned makes a written admission of such

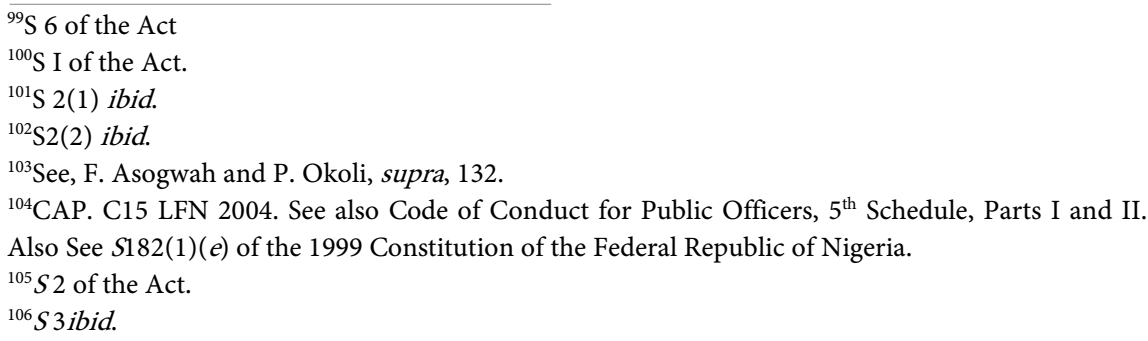


breach or non-compliance, no reference to the Tribunal shall be necessary on this ground. This gives the public officer involved an opportunity to save himself. This admission will also save the Tribunal and its personnel time and resources which would have been engaged in prosecution of the matter.

Public officers under this Act are prohibited from maintaining and operating foreign bank accounts. ${ }^{107}$ According to the Second Schedule, the public officers affected are:

$>$ The President and Vice President

$>$ The President and Deputy President of the Senate, Speakers and Deputy Speakers of Houses of Representatives and the Houses of Assembly of States, and all members and Staff of Legislative Houses.

$>$ Governors and Deputy Governors of States.

$>$ Chief Justice of Nigeria, Justices of the Supreme Court, President and Justices of the Court of Appeal, all other Judicial Officers and all Staff of Courts of law.

Attorney General of the Federation and Attorney General of each State.

$>$ Ministers of Government of the Federation and Commissioners of the Governments of the State.

Chief of Defence Staff, Head of the Army, Navy, Air Force and all members of the Armed Forces of the Federation.

> Inspector-General of Police, Deputy Inspector-General of Police and all members of the Nigeria Police Force and other Government Security agencies established by law.

> Secretary to the Government of the Federation, Head of Civil Service, Permanent Secretaries, Directors-General, and all other persons in the Civil Service of the Federation or of the States.

$>$ Ambassadors, High Commissioners and other officers of the Nigerian Mission Abroad.

All Staff of Universities, Colleges and Institutions owned by and financed by Federal or State Governments or Local Government. In fact all persons employed or appointed into any public officer from Local to Federal Government.

7) The Criminal/Penal Code Act.

The Criminal and Penal Code contain provisions which deal with the offence of corruption. These provisions came into existence when corruption was not a more serious offence in its incidence and effects than other code offences. They deal mainly with the straightforward cases of demanding, receiving, and offering gratification for some favour and cannot encompass modern and sophisticated methods corruption. The criminal code provisions are very technical and compartmentalized resulting in so many loopholes that often, persons who are obviously guilty of the offence charged are set free on technical grounds; for instance that the charge was brought under wrong section. ${ }^{108}$ The problem became

\footnotetext{
${ }^{107}$ Section 7 ibid.

${ }^{108}$ See, R v Anyaleme (1943) 9 WACA, 23; $R$ v Mercellus (1953) 29 NLR, 155.
} 
so pronounced that in Amaeechi $V$. COP ${ }^{109}$ the court observed thus:

We would only add, and repeat what has been said in the past that the law relating to official corruption and kindred offences is not easy and that the advice of the law officers should be sought whenever possible before proceedings are taken. ${ }^{110}$

The provisions in the two codes focus on public officers. The private sector is unaffected. There is also lack of special institutional framework for dealing with the code offences.

The penal code provisions on corruption are wide, lucid and less technical than the Criminal Code provisions. ${ }^{111}$ They cover not only the usual cases of corruption where a public servant receives gratification for something done or omitted to be afterwards done but also cases where he accept a valuable thing without consideration or for inadequate consideration from a person likely to be concerned in business about to be transacted by the public servant. ${ }^{112}$ An effort was made in 1966 to improve the Criminal Code Provisions on corruption and to close some of the loopholes. The major provisions on corruption (sections 98, 100 and 114 to 116 ) were repealed by the Criminal Justice (Miscellaneous Provisions) Act (No. 84) 1966. ${ }^{113}$ Under Section 98, the receiver of the bribe must be employed in the public service. Section 1 of the Code defines a person employed in the public service. So, in $\mathrm{R}$ v. Eka, ${ }^{114}$ it was held that in a charge under section 98 , it is essential that there should be evidence of the nature of the duties of the public officer.

From the provisions of the Criminal Code as it relates to corruption, it is indeed very clear that the code cannot sustain any serious effort to fight corruption. In the face of sophistication in various corruption practices across different spheres of the economy in Nigeria, the Criminal Code and Penal Code Act has become a piece of legislative antiquity. ${ }^{115}$

8) The Corrupt Practices and Other Related Offences Act. ${ }^{116}$

This Act was enacted in 2000 under the democratic regime of Chief OlusegunObasanjo. It appears to be a major landmark and sign-post for the effective and efficient fight against corruption by that regime. In June 2000 at assenting to the Act, President OlusegunObasanjo declared thus:

We acknowledge that we may not be able to eradicate corruption in its totality overnight, but we can at least begin by laying down the foundations of a moral and ethnical society... I believe the implementation of this Act will

${ }^{109}(1958)$ NRNLR, 123.

${ }^{110}$ At page 126.

${ }^{111}$ See, Penal Code, Chapter X.

${ }^{112} \mathrm{~S} 119$ Penal Code.

${ }^{113}$ They were replaced by new provisions i.e. sections $98,98 A, 98 B, 98 C$ and $98 D$. However the new provisions still do not encompass corruption in the private sector and have not widened the scope of corruption.

${ }^{114}$ [1960] N.R.N.L.R. 130

${ }^{115}$ Asogwah, F. and Okoli, R. Supra 150.

${ }^{116}$ CAP. C31 LFN 2004. 
go a long way in purifying our society.

This Act is an adumbration of Sections 98 to 104 of the Criminal Code Act and other similar Codes in the Southern States of Nigeria dealing with bribery and corruption before its enactment. The same is applicable to the relevant sections of the Penal Code operating in the Northern States of the Country. The Act allows the operation of these enactments alongside it. Hence the police and other prosecuting authorities either at the Federal, State or Local Government levels can still charge a culprit under these Codes or any other law in force prohibiting bribery and corruption in any part of Nigeria.

The Act is a lengthy one of about 71 Sections. Section 3 provides for the establishment of the Independent Corrupt Practices and Other Related Offences Commission. The Act provides that the Chairman shall be a person who has held or is qualified to hold office as a judge of a superior court of record. ${ }^{117} \mathrm{Sec}-$ tion deals with the duties of the commission. It provides that it shall be the duty of the commission:

a) to receive and investigate any report of conspiracy to commit, attempt to commit or the actual commission of corruption and to prosecute offenders;

b) to examine the practices and procedures of public organizations and where the commission finds such practices and procedures to aid or facilitate fraud or corruption, to direct and supervise their review;

c) to instruct, advice and assist agencies and parastatals on ways by which fraud or corruption may be eliminated minimized;

d) to advise heads of public institutions on changes of practices and procedures that will reduce the likelihood or incidence of bribery, corruption and related offences;

e) to educate the public on and against bribery corruption and related offence; and

f) to enlist and foster public support in combating corruption.

Offences and punishment of same are provided for in Sections 8 to 26. Some of these sections are apparently similar in context to the provisions of the Criminal Code Act; for instance, Section 8 which deals with the offence of accepting gratification. If there is any remarkable difference between these sections and those of the Criminal Code Act, it would be the amount of fines ${ }^{118}$ and provisions of section 23. Section 23 makes it mandatory for a public officer to report gratification given, promised or offered to him and provide the name of the person who gave, promised or offered such gratification, to the commission or police. ${ }^{119}$ Again, any person from whom gratification has been solicited or obtained or attempts have been made to obtain gratification shall report such action together with the name and full description of the person to the commission ${ }^{117} \mathrm{~S} 3(4)$.

${ }^{118}$ For instance, S 22(6) or Corrupt Practices and Other Related Offences Act provides that any person or public officer who commits an offence under subsection (1) and (2) of the Section is liable on conviction to a term of imprisonment for seven (7) years or one million naira fine.

${ }^{119} \mathrm{~S} 23(1)$ of the Act. 
or police. ${ }^{120}$ The punishment for the contravention of subsections (1) and (2) of this section on conviction shall be liable to a fine not exceeding one hundred thousand naira or for a term not exceeding two (2) years imprisonment or both. ${ }^{121}$

The Act is a comprehensive legislation with Seventy-one (71) sections. Sections 27 and 42 provides for power to investigate crimes, searches on premises for persons and property, seizure of movable and immovable property, arrest and detention of persons and property of suspects. It is instructive to note that under this Act, "every offence under this Act shall be a bailable offence for the purpose of the Criminal Procedure Act or Code."122

The Act is self-executing as it has provisions relating to evidence and procedure adoptable during trial in court. ${ }^{123}$ It should be noted that nothing contained in the Act derogates from the powers of a Police Officer to investigate any offence under the Act or to prosecute any person in respect of such offence provided that the Police shall bring to the attention of the Commission every case of bribery, corruption or fraud being investigated or prosecuted by them after the coming into force of the Act. ${ }^{124}$ It is important to evaluate section 53 of the Act which presumes an accused guilty of the offence of gratification or any other offence under sections 8 to 19 of the Act, until the contrary is proved in Court. This patently is contrary and inconsistent with section 36(5) of the 1999 Constitution (As Amended). ${ }^{125}$ It is a fundamental right that a person is presumed innocent until found guilty by a court of competent jurisdiction and otherwise.

9) The Economic and Financial Crimes Commission Act. ${ }^{126}$

Economic and Financial Crimes Commission (Establishment, etc) Act of $4^{\text {th }}$ June 2004 is an Act of the National Assembly that repealed the Financial Crimes Commission (Establishment) Act 2002. The new Act has forty-seven (47) sections and schedule. The role of EFCC in combating corruption in Nigeria lies within the legal framework relating to its powers and functions. These roles are as provided for by sections 6 and 7 of the Act. The roles assigned to this commission are comprehensive and enlarged in nature. In summary, the commission is empowered to prevent any form of economic and financial crime in $\mathrm{Ni}$ geria; investigate and prosecute those involved on money laundering, embezzlement, bribery, smuggling, illegal arms transactions, oil bunkering, unauthorized mining, human trafficking, child labour, tax related offences, cyber crimes, foreign exchange malpractices, currency counterfeiting, tracking, freezing as well as confiscation of sleaze wealth including those of terrorist outfits.

Specifically, Section 7 cloths the commission with the powers of the coordi-

${ }^{120} S 23(2)$ ibid.

${ }^{121} S 23(3)$ ibid.

${ }^{122} S 42$ (1) ibid.

${ }^{123}$ Ss 53 to 60 Ibid.

${ }^{124} S 69$ Ibid.

${ }^{125}$ Compare Section of the Act with the Proviso to $S 36(5)$ of the Constitution as to inconsistency or otherwise.

${ }^{126}$ CAP, E1 LFN 2004. Hereinafter referred to as "EFCC". 
nating agency for the enforcement of the provisions of such other laws as:

1) The Money Laundering Act, 2004;

2) The Advance Fee Fraud and Other Related Offences Act, 1995;

3) The Failed Banks (Recovery of Debt and Financial Malpractices in Banks) Acts (As Amended);

4) The Banks and Other Financial Institutions Act, 1991 (As Amended);

5) The Miscellaneous Offences Act; and

6) Any Other law or regulation relating to economic and financial crimes, including the Criminal Code and Penal Code.

Significantly, the Act empowers the Commission to arrest anyone suspected of economic crimes, investigate the crimes and subject the suspect to declaration of his assets while the investigation is going on. ${ }^{127}$ Also, the commission is empowered to apply ex parte to the High Court for any interim seizure and forfeiture of the assets of the suspect and the court if satisfied that a prima facie evidence has been laid out, make an interim order forfeiting the property to the Federal Government. ${ }^{128}$ Again, the Act empowers the Commission to freeze the account of the suspect in the bank through an ex parte application and order of the High Court. ${ }^{129}$

Section 40 of the Act provides thus:

"subject to the provisions of the Constitution of the Federal Republic of Nigeria, 1999, an application for stay of proceedings in respect of any criminal matter brought by the Commission before the High Court shall not be entertained until judgment is delivered by the High Court.”

This particular provision increased the boldness and bravery of the commission to combat corruption and economic crimes in Nigeria. Commenting over this provision, Late Chief GawiFawehimi (SAN) noted that:

"What pains some lawyers most is that they cannot frustrate the effectiveness of the EFCC by seeking an order to stay proceedings in the High Court while interlocutory appeals are filed with the sole purpose of delaying justice in matter pending before that High Court against the person accused of economic crimes." 130

EFCC as an institution has made remarkable successes and has been bedeviled with daunting challenges which include among others delayed cases in court as a result of unnecessary adjournments sought by defence counsel and long adjournment acceded by the courts. These delay tactics engaged by defence counsel has affected the number of convictions recorded by the commission. Again, sections 35(2) and 36(11) of the Constitution of the Federal Republic of Nigeria provide defence to the accused. These Sections provide for the right to remain silent and the freedom from self-incrimination respectively.

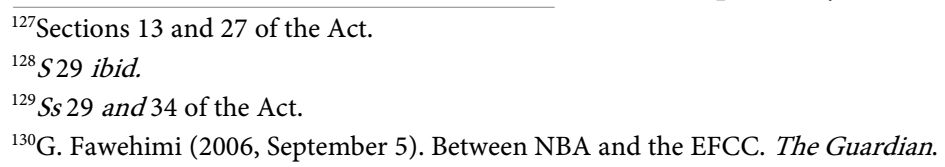




\section{Establishment of Independent and Special Courts for the Trial of Corruption Cases in Nigeria}

The necessity for an independent and special court was identified by the National Committee on Corruption and Other Economic Crimes in Nigeria headed by Honourable Justice KayodeEso. This committee was set up by the Ibrahim BadamosiBabangida regime. The terms of reference of this committee were:

1) to identify the causes and possible extent of corruption in Nigeria;

2) to examine the deficiencies in the existing legislation on corruption in $\mathrm{Ni}$ geria: and;

3) to suggest remedies which would lead to the curbing of the incidences of corruption including suggested improvements to the existing legislation.

In carrying out these terms of reference and in the bid to give the country the best of its endeavour, this committee engaged in comparative study of other jurisdictions. In the process, it visited Hong Kong, Zambia, and Zimbabwe which had similar problems of corruption and drew from the experience of these countries in making recommendations. The Report of this Committee identified the defects in Nigeria's existing laws; it set out the causes of corruption in the country and suggested legislative and non-legislative remedies. Under Legislative Remedies, the Committee proposed "A Compendium of Laws on Corruption and Other Economic Crimes." ${ }^{\prime 31}$ The Report included draft legislation on the following:

1) Corruption and Economic Crimes;

2) Independent Commission Against Corruption (ICAC);

3) Private Investigations; and

4) The Corrupt Practices Court. ${ }^{132}$

Therefore, the need to establish an independent and special corruption court was conceived in Nigeria for over 32 years during the regime of Military President Ibrahim Babangida. The Hon-Justice KayodeEso's Committee after a comparative study of jurisdictions with similar corruption incidences recommended for a separate corruption court as a means of tackling the menace in the country. The philosophy behind this call for a special court was for corruption cases to be expeditiously handled by judges who would have been specially retrained to handle such cases. The legislation drafted by this committee for the corrupt practiced court contained Rules of Procedure which would make trial less cumbersome and time-saving against the Rules of Procedure in the regular courts today. For this Committee, any fight against corruption without independent and special court created for prosecution of corruption cases will be a ruse, subterfuge and a waste of time and resources of the nation.

In Nigeria today, corruption and economic crimes cases have been subjected to inordinate delays in our courts which are congested with numerous other cases. Defence lawyers adopt the tactics of frivolous and unwarranted adjourn-

${ }^{131}$ C.O. Okonkwo. (2011). Legal and Institutional Mechanisms Against Corruption in Nigeria, in I. A. Ayua \& B. Owasanoye (ed), supra, 273.

${ }^{132}$ Ibid, 274. 
ments for the purpose of stalling proceedings. The experience is that looters of the nation's treasury facing prosecution in regular courts with the connivance of their lawyers and warped judges employed a mixed bag of deception-interlocutory applications, ex parte motions and perpetual injunctions, among others, to stifle corruption proceedings. This explains why the prosecution of the former Governors that left office in 2007 has remained at rudimentary stages for over ten (10) years. Economic and Financial Crimes Commission has about 43 high profile corruption cases in court since 2007 which include 16 former governors that are still pending in court. Other cases relate to the Oil Subsidy Scandal, Money laundering and Violation of the Public Procurement Act. ${ }^{133}$ These cases are on hold as a result of preliminary objections, trial within trial, interlocutory appeals at the Supreme Court, assigning of trial judges of election petition tribunals, abuse of court processes, illness of defendants or counsel, filing of fresh charges among others.

\subsection{The Judicial Organ and Creation of Courts in Nigeria}

On Monday, $18^{\text {th }}$ September, 2017, the Chief Justice of Nigeria (CJN), Hon. Justice Walter Nkanu Samuel Onnoghen, at a special session organized to usher in the 2017/2018 legal year and to swear in 29 new Senior Advocates of Nigeria, ordered the Chief Judges of Courts in Nigeria to designate at least one Court in their jurisdictions as a special court solely for the purpose of adjudicating on corruption and economic crimes cases. The CJN directive has thrown open flood-gate of legal analysis and argument as to the constitutionality of such special courts envisaged by this directive.

It must be stated that all courts of superior record in Nigeria are established by section 6(3) of the 1999 constitution of Nigeria (As Amended). Section 6(4)(a) of the Constitution empowers the National Assembly and State Houses of Assembly to establish or create courts other than the ones specifically denominated and created by subsection (5). From the foregoing, it is crystal clear that legally, it is only the National and State Assemblies that can establish or create a court, the CJN or State Chief Judges lack the legal capacity and jurisdiction to do so.

Similarly, Section 36(1) of the same constitution provides thus:

In the determination of his civil rights and obligations, including any question or determination by or against any government or authority, a person shall be entitled to a fair hearing within a reasonable time by a court or other tribunal establishment by law and constituted in such manner as to secure its independence and impartiality.

\footnotetext{
${ }^{133}$ The Scoop, "EFCC Gives Breakdown: 43 Corruption Cases in Court", The Scoop, 2017, $<$ www.thescooping.com $>$ retrieved on $18^{\text {th }}$ Nov. 2017. Some of the pending high profile cases are those preferred against Ex-Governors, Orji Uzor Kalu (Abia) Danjuma Goje (Gombe), Jolly Nyame (Taraba), Joshua Dariye (Plateau) Saminu Turaki (Jigawa), the Late Audu Abubakar (Kogi), Timipreye Sylva (Bayelsa), Murtala Nyako (Adamawa), Sule Lamido (Jigawa), Adebayo Alayo-Akala (Oyo), Rashidi Ladoja (Oyo), Chimaroke Nnamni (Enugu), Gbeya Daniel (Ogun), Aliya Akwe Doma (Nassarawa), Attahini Bafarawa (Sokoto), Abdullahi Adamu (Nassarawa) and others.
} 
Again, Section 46(1) of the 1999 Constitution provides thus:

Any person who alleges that any of the provisions of this chapter has been, is being or likely to be contravened in any state in relation to him may apply to a High Court in that state for redress.

These Constitutional provisions are sacrosanct and non-derogable in character. It will be unconstitutional for any High Court to be singled out particularly to try only corruption cases. This would amount to illegal amendment of the constitution especially Section 272(1) which provides for the jurisdiction of the High Court of a state. ${ }^{134}$ The provision in Section 46(3) that:

The Chief Justice of Nigeria may make rules with respect to the practice and procedure of a High Court for the purposes of this Section...

This cannot be construed to inure power to the CJN or any Judge for that matter to create or establish courts which such power is conferred only on the Legislative organ. It will be usurpation of power by the judicial organ in doing this. The contemplation of Section 46(3) is the issuing of Rules of Practice which orders are made by the $\mathrm{CJN}$ for the purposes of regulating the practice and procedures in court which must be complied with by members of the bar and others.

Whilst passion and drive of the CJN is to safeguard the nation and lead judicial weight to the fight against corruption, it is unlikely that CJN or Chief Judges of States can create special courts by fiat as their legality would be called to question since the constitution does not confer such powers on them.

\subsection{Special Court for Prosecution of Corruption}

Special Courts are not judicial anomalies. They are Courts within the judicial branch which generally address only one area of law or have specifically defined powers. Special Courts differ from general jurisdiction courts in several other respects besides having a more limited jurisdiction. Under this arrangement cases will be disposed off expeditiously. This is because special courts do not follow the same procedural rules that general jurisdiction courts adopt.

For the establishment or creation of Special Courts in Nigeria judicial system, a new bill for the enactment of an Act for a Special Court for Corruption and the further amendment of the Constitution are needed. This legal framework will provide procedural regulation for the special circumstances that warranted the courts in the first place. Their peculiarity may necessitate a situation whereby they would require the jury system because of the integrity and independence of the people involved. It is only the promulgation of this law and the amendment of the Constitution that can guarantee effectiveness and effectuality of the functioning of these courts. ${ }^{135}$ Again, it is hoped that the new act and the further ${ }^{134}$ See also Section $257(1)$ of the Constitution for the jurisdiction of the High Court of the FederalCapitalTerritory.

${ }^{135}$ Similar issues were raised during the nascent stage of the National Industrial Court. This Court encountered various challenges until the enactment of the National Industrial Act and the Subsequent amendment of the 1999 Constitution which made it a superior court of record. 
amendment of the constitution shall provide for life imprisonment for any person convicted for corruption and kindred crimes.

The establishment of special courts for prosecution of corruption in Nigeria should form integral part of Nigeria's legal response to corruption. Malaysia and Singapore are among countries that have used the strategy to deepen their anti-graft war. Malaysia has 14 of such Special Courts which have revolutionized corruption trials there. The country also has "name-and-shame" database where it uploads names of those that have been convicted of corruption which the United States has adopted as a global model. ${ }^{136}$

An effective judiciary is a powerful weapon against corruption. Special Court system must be complemented with broader judicial reform. There must be put in place fair judicial salaries and pensions to make court personnel less vulnerable to bribery. These should reflect experience, performance and an honest track record.

\section{Conclusion and Recommendations}

In Nigeria, corruption has posed serious developmental challenges. It has undermined democratic dividend and good governance by flouting or even subverting formal accountability processes. As a result infrastructural amenities such as water, electricity, roads, education, Health-care and other good things of life which ought to be provided for the average Nigerian cannot be provided. Rather those in government have been in government before, build edifices in their villages and major cities, and buy choices cars. More generally, corruption erodes the institutional capacity of government as procedures are disregarded, resources are siphoned off and public offices are bought and sold. In the final analysis, corruption undermines the legitimacy of government and such democratic values as trust and tolerance. ${ }^{137}$

Tied to this point is the fact that corruption makes the polity highly susceptible to poverty, unemployment, illiteracy and disease. These lead to vicious cycle of armed conflict, violence and civil unrest. Enthronement of bad leaders in this country has resulted into harvesting monumental corrupt government and the crises that trail upon the country. The uncanny display of affluence by treasury looters in Nigeria has exposed the nation to a possible regrettable implosion. The youths are seriously asking questions about why they cannot be guaranteed a job after completing their compulsory One Year Youth Service Programme and many more. The resources that would have been used to build factories or industrialize the country were siphoned by a plunderous cabal who became leaders in Nigeria. The resultant effect of this realization is grief and frustration which generates civil unrest, then graduates to violence and ultimately armed conflict as we have in the Niger-Delta, Independent People of Biafra and the Northeast Nigeria.

To fight corruption, legal and institutional framework must be polished and

${ }^{136}$ Punch, “Corruption Cases: Special Courts at Last," Punch of September 25, 2017.

${ }^{137}$ L. Akpogena. (2006, April 16). Political Corruption and Good Government. Thisday. 
tightened for effective and efficient result. However, the CJN's intervention by directing Chief Judges of states to create special courts for the exclusive trial of corruption cases, is worthy of commendation. To make the directive a success, there is the need for the heads of different courts, ${ }^{138}$ to issue practice Directions to accelerate the determination of corruption cases. In addition, the Supreme Court (Criminal Appeals) Practice Directions 2013, Court of Appeal (Criminal Appeals) Practice Directions 2013, and Court of Appeal (Fast Track) Practice Directions 2014, as well as the Federal High Court Practice Directions 2013 issued by the heads of the respective courts should be put to use as they are designed to give priority to the trial and appeals arising from cases of corruption, money laundering, terrorism, rape, kidnapping and human trafficking.

To obviate undue delay in the determination of corruption cases, the Practice Directions have made special provision for the service of processes on parties by electronic mail addresses, facsimile numbers, GSM telephone numbers and others. Also, the Supreme Court has upheld the constitutionality of section 306 of the Administration of Criminal Justice Act with respect to the abolition of stay of proceedings in criminal trials in all federal courts. Again, defence counsel who conspired with their clients to frustrate the prosecution of corruption cases should be made to pay punitive cost while not more than two (2) lawyers, should appear in court for any of the parties in corruption cases. ${ }^{139}$

As stated earlier, the legal establishment and creation of independent and special courts for the prosecution of corruption is the impetus and national response required at this time. The present writer is aware that as part of an anti-corruption policy, President Mohammed Buhari sent an executive bill for the establishment of a special court clothed with exclusive jurisdiction to try corruption cases, to the National Assembly. Although it was submitted over a year ago, the National Assembly has yet to pass the bill. To curb inordinate delays in our courts, which are congested with many other cases, it is imperative to pass the bill and establish the special court for corruption cases. Again, the second and final stanza of this project will be crucial action of the further amendment of the 1999 Constitution to raise the special court legal status to a court of superior record.

We recommend that the new Act establishing the Special courts should provide life imprisonment as punishment for the offence of corruption. The provision should be accentuated by injecting same provisions in the Constitution after the further amendment as proposed by this work.

Another recommendation is that government should ensure responsible and responsive management and application of resources for sustainable development. This will involve the collaboration of local governments, private sector, civil society organization, non-governmental organization, states and federal

\footnotetext{
${ }^{138}$ For instance, Chairman of Code of Conduct Tribunal, Chief Judges of States and the FederalCapitalTerritory.

${ }^{139}$ F. Falana. (2017, September 21). Kudos to CJN for Creating Special Courts For Corruption Cases. Sahara Reporter.
} 
government. This collaboration will ensure that:

1) participation of the people at the local level where service delivery is essential. This is because projects and programmes must have local content and local population preference;

2) resources meant for the people at the lower level are not embezzled or siphoned to unapproved ventures in other places to detriment of the local people;

3) that there is transparency in the allocation and application of resources to agreed objectives and goals.

The end result of the above would be job creation, provision of education and good health-care, infrastructural development and decent environment.

On the issue of Fulani Herdsmen, we recommend a national programme/policy or legal framework for ranching across Nigeria. Cattle-breeding and rearing is an agricultural business which individuals engaged in it must be ready to make financial input into it. The present situation where cattle breeders and rearers add little or nothing into the trade and reap bountifully should be discouraged. They should be ready to feed their cattle with their money just as poultry, fishery and other animal farmers buy land, build, confine and feed their animals in that closet. This is one sure way of curbing and deflating the tension and acrimony generated by herdsmen and farmers conflicts. More importantly, the security agencies must rise up to the occasion by arresting and prosecuting herdsmen that slaughter farmers and destroy their crops.

\section{Conflicts of Interest}

The authors declare no conflicts of interest regarding the publication of this paper.

\section{References}

Adetiloye, T. (2014). The Root Cause of Boko Haram and Other Insurgent Groups in Nigeria. Sahara Reporters.

Amnesty International (2016). Boko Haram: Civilians Continue to Be at Risk of Human Rights Abuses by Boko and Human Rights Violations by State Security Force.

Asogwah, F., \& Okoli, P. (2008). Economic Crimes and National Development. Enugu: Institution for Development Studies.

Atuobi, S. (2007). Corruption and State Instability in West Africa. An Examination of Policy Options. RAIPTC Occassional Papers.

Aye, J. R. A. (2002). Political and Social Consequences of Corruption in Corruption and Development in Africa. In Proceeding of a Seminar Organized by the Ghana Academy of Arts and Sciences.

Ayua, I., \& Bolaji, B. (2002). Problems of Corruption in Nigeria. Zaria: The Wealth Press.

Bowman, J. (1991). Introduction to Ethical Theory and Practice in Public Management. In Ethical Frontier in Public Management. Seeking New Strategies for Resolving Ethical Dilemmas (pp. 110-150). San Francisco, CA: Jassey Base.

Chabal, P., \& Daloz, J. P. (1999). Africa Works. Disorder as Political Instrument. Oxford: James Curry. 
Clark, T. (1991). A Right Honourable Gentleman. The life and Times of Alhaji Sir AbubukarTafawa Belewa. Zara: Hudahudo Publishing Company Ltd.

Cook, D. (2014). The Rise of Boko Haram Insurgency in Nigeria. The Imperative of Adopting the Mechanism of the Rule of Law.

David, J., \& Gould, J. D. (1999). Administrative Corruption: Incidence, Causes and Remedial Strategies. In A. Farazmand (Ed.), Handbook of Comparative and Development in Public Administrative (pp. 467-484). New York: Marcel Dekker.

Gammer, B. (1999). Black's Law Dictionary (8th ed.). USA: West Publishing Co.

Human Rights Watch (2017). Abuses by Boko Haram, Conduct of Security Forces, International and Political Violence. World Report 2016.

Ikejiani, O. et al. (1968). Nigeria: Political Imperative-Desiderata for Nationhood and Stability. Enugu: Fourth Dimension Publishing Co. Ltd.

Johnston, M. (1989). The Political Consequences of Corruption. A Reassessment in Corruption Polities.

Kukah, H. (1999). Democracy and Civil Society in Nigerian. Ibadan: Spectrum Books Limited.

Le Billion, P. (2003). Buying Peace or Fuelling War. The Role of Corruption in Armed Conflict. Journal of International Development, 15, 413-426.

https://doi.org/10.1002/jid.993

Lo, T. W. (1993). Corruption and Politics in Hong Kong and China. Buckingham: Open University Press.

Martin, L. S., \& Leriz, G. S. (2000). Corruption, Culture and Market. In Culture Matters (pp. 58-78). New York: Basic Books.

Nye, J. (1957). Corruption and Political Development: A Cost-Benefit Analysis. In M. U. Ekpo (Ed.), Bureautic Corruption in Sub-Saharan Africa: Towards a Search for Causes and Consequences (pp. 201-220). Washington DC: University Press of America.

Pavarala, V. (2010). Interpreting Corruption Elite Perspectives in India. New Delhi: Sage Press.

Seidman, R. (1974). Corruption: A Case Study in Deviance. In P. Brietzeke (Ed.), Source Book of Ethiopian Law and Development (pp. 320-360). Stoke: Basic.

Taiwo, O., \& Onalaja, K. (2001). How Polygamy Wrecks Nigeria, Africa. Capwona Books.

Theobald, R. (1990). Corruption, Development and Underdevelopment (6th ed.). Basing Stoke: Mamillian. https://doi.org/10.1007/978-1-349-20430-4

Tony, T. (2017). Price Nigeria Is Pay for Corruption. In V. Dik (Ed.), Corruption in Nigeria. A New Paradigm for Effective Control, Africa Economic Analysis (pp. 66-89). Ilorin: Hope Publishers Ltd. 